\title{
Passive Optical Networks Progress: A Tutorial
}

\author{
Tomas Horvath ${ }^{1,2, *,+(\mathbb{D}}$, Petr Munster ${ }^{1,2,+} \mathbb{C}$, Vaclav Oujezsky ${ }^{1,+}+\mathbb{C}$ and Ning-Hai Bao ${ }^{3,+}$ \\ 1 Department of Telecommunication, Brno University of Technology, Technicka 12, \\ 61600 Brno, Czech Republic; munster@feec.vutbr.cz (P.M.); oujezsky@feec.vutbr.cz (V.O.) \\ 2 Department of Optical Networks, CESNET a.l.e., Zikova 4, 16000 Prague, Czech Republic \\ 3 School of Communication and Information Engineering, Chongqing University of Posts and \\ Telecommunications, Chongqing 400065, China; baonh@cqupt.edu.cn \\ * Correspondence: horvath@feec.vutbr.cz; Tel.: +420-541-146-923 \\ + These authors contributed equally to this work.
}

Received: 2 June 2020; Accepted: 26 June 2020 ; Published: 1 July 2020

\begin{abstract}
For many years, passive optical networks (PONs) have received a considerable amount of attraction regarding their potential for providing broadband connectivity to almost every citizen, especially in remote areas where fiber optics can attract people to populate regions that have been abandoned. Error-free connectivity without dropouts can offer new opportunities to communicate, earn money and enjoy cultural events. Transmission speeds are multigigabit with distances of a few tens of kilometers; these specifications were previously reserved for high-speed and long-haul backbone networks. PONs can also support a new class of applications, such as accurate time transfer or distributed fiber sensing and follow new trends in open networking. An outline of past and current standards and standards that have been proposed for the latest generation of multigigabit PONs is provided.
\end{abstract}

Keywords: passive optical networks; APON; BPON; GPON; XG-PON; NG-PON2

\section{Introduction}

The Internet is just an ordinary thing in the lives of billions of people, and emails, file sharing, messaging, cloud services, video calls, online gaming and online movie streaming are taken for granted. In some places, people do not have access to drinking water but have access to the Internet. This access is made possible by the enormous transmission capacity that is available in the core fiber networks using coherent optical transmission equipment, offering hundred gigabit per second transmission speeds (400 Gbps in 2018); with the help of wavelength multiplexing, the total capacity can reach tens of terabits per second. The maximum capacity of the core Internet fiber networks is just one part of the story-it is even more important that end-users can access that massive volume of data [1]. Wireless networking with mobile phones, tablets and other wireless devices is responsible for tremendous growth in Internet traffic, but optical fiber is still the most promising candidate to satisfy any foreseeable data traffic [2-4].

Since the inception of the Internet and the World Wide Web (WWW), bandwidth consumption among common users has continually increased. Video applications demand the highest consumption because high-definition television (HDTV) has become almost obsolete and modern users are seeking super HDTV, which is also called $4 \mathrm{k}$, while TVs with even better resolution, such as $8 \mathrm{k}$, are available on the market $[5,6]$. However, $8 \mathrm{k}$ is not as widespread due to a lack of real content (i.e., movies available in these super HD resolutions). HDTV streams may consume megabits per second, while $8 \mathrm{k}$ may consume a maximum of one hundred megabits per second. Therefore, Internet services must be able to offer additional bandwidth, especially end-user demand for bandwidth, which is continuously increasing both in access networks and core networks [7]. 
A well-known and respected visual networking index (VNI) by Cisco is available online [7] and confirms the substantial data growth: global Internet Protocol (IP) traffic will increase nearly threefold over the next 5 years and will have increased 127-fold from 2005 to 2021. IP traffic will increase at a compound annual growth rate (CAGR) of $24 \%$ from 2016 to 2021 . Annual global IP traffic will reach 3.3 ZB (a zettabyte is 1000 exabytes) by 2021. In 2016, global IP traffic was 1.2 ZB per year or 96 EB per month. By 2021, global IP traffic will reach $3.3 \mathrm{ZB}$ per year, or $278 \mathrm{~EB}$ per month. Although these data are predictions, IP traffic is significantly increasing every year. Note that some parts of Africa with a very young population do not have access to the Internet, which indicates that stagnation in growth is not expected.

Although the price of fiber is low, underground installation is the most expensive part and is usually linked to legal issues. Thus, when fiber is laid/buried in the ground, one fiber must be used multiple times without installing any active devices along the way. Passive optical networks can solve this problem.

Bandwidth consumption is dependent on many factors. An interesting resolution for introverted and extroverted people, nations and continents is explained in [8]. Bandwidth consumers are described as Telhomers in the United States of America (USA) and Canada. Telenese live in Asia and Europeans are described as Cafeneans. Although it may not appear to be a serious approach, the difference between climate and temperament among different continents and nations must be respected to achieve the best results. One example pertains to rural remote areas of Sweden [9]. Even young people are willing to return to the empty countryside if they can use a broadband Internet connection to communicate with friends and families, watch the news and work in home offices.

Passive optical networks (PONs) have been attracting attention as a promising access technology for more than 20 years with the first International Telecommunication Union (ITU) Recommendation G.983.1, which was published in 1998 [10], featured (then) popular asynchronous transfer mode (ATM) technology and related ATM-based PONs.

The first mention of optical fibers usage in passive access networks was published in 1987 by Stern and colleagues [11]. The change in the transmission medium from copper to silica fiber required the connection of active devices to provide the conversion of optical signals to electrical signals, which is not used in contemporary PONs.

This concept was referred to as an optical distribution network (ODN). ODN concepts that were developed in 1987 remain preserved, with some changes. PONs are assembled from passive devices, such as optical fibers, connectors and power splitters, with active elements such as optical line termination (OLT) devices and optical network units (ONUs). Technologies and principles of PONs have been actively researched and developed over the last three decades and remain a focus of researchers. As a result, different PONs are available that encompass not only access but also metropolitan distances and multigigabit data rates.

PONs are similar to another technology: fiber to the home (FTTH). The FTTH Council was formed in 2001 to promote FTTH concepts in North America, especially the USA and Canada. Although Europe as whole was not as active in this area of networking (some countries were), the importance of PONs and FTTH was recognized by the European Union (EU). The EU aims to financially support the commissioning of fast optical networks, at least $30 \mathrm{Mbps}$ for each customer and $100 \mathrm{Mbps}$ for new connections until 2020. The EU gives more attention to next-generation (NG) optical access networks [12]. Despite the immense popularity of wireless technologies, fiber is recognized as the important part of many broadband initiatives, for example, in large international corporations such as Google [13] or AT\&T [14].

Many current solutions specify how to terminate optical fiber at an end-user, and FTTH is not considered to be the only solution. Generally, fiber to the x (FTTx) is the name of the convention, where the letter " $x$ " expresses a technology. FTTH is only a part of the generalized term FTTx, and these technologies are very popular and frequently deployed; Internet services providers (ISPs) have to find a trade-off between price and penetration [15]. For example, for fiber to the building (FTTB), optical fiber 
is installed in optical splice boxes in buildings, and then, different transmission mediums (such as copper wire) are used to carry the signal into customer apartments. Other solutions employ edge boxes (e.g., switches or routers) in a building that are powerful, small and have low power consumption. These boxes provide optical interfaces with optical cables that reach individual apartments equipped with equipment that have optical receivers and usually use Ethernet for services such as Internet protocol television (IPTV).

A PON network is usually created by point-to-multipoint (P2MP) infrastructure, as depicted in Figure 1, where part "(a)" presents the base topology with a splitter represented by a particular standard, and part "(b)" presents the most popular solution with the cascade ordering of splitters. The composition can differ with regard to an ISP. The first splitter is used after an active OLT port to provide an effective number of ONUs that are connected to the OLT port. The single port of an ONU has the limitation of time slots, and therefore, full capacity of the ONU is unreachable. Another type of networking is point-to-point (P2P), which is more complex and requires fiber for every aggregation switch. The difference is highlighted in Figure 2.

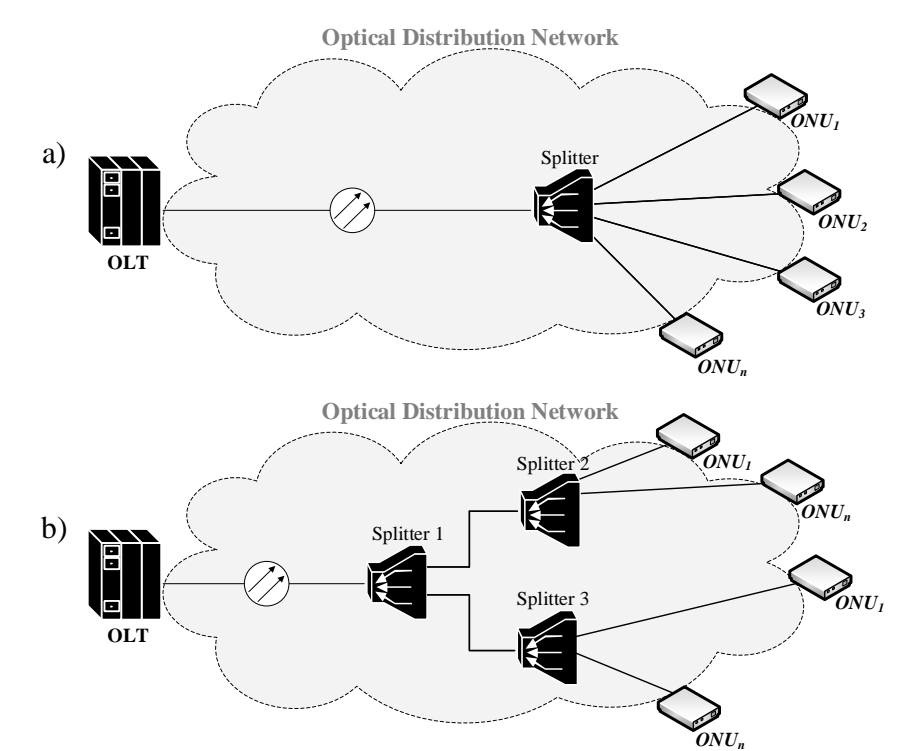

Figure 1. Basic passive optical network (PON) structure (a) according to standards, (b) most common PON structure in real networks.
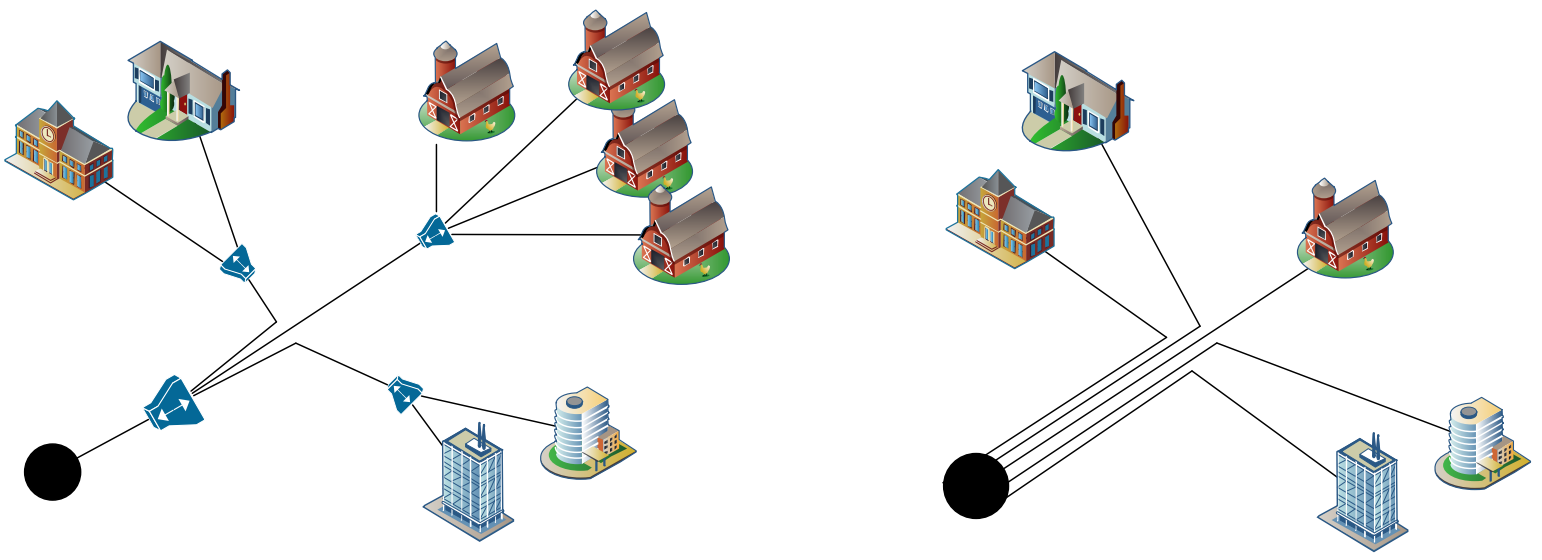

Figure 2. PON topology (point-to-multipoint (P2MP) scheme) and point-to-point (P2P) architecture on the right side.

The development of new technical solutions and standards is not limited to transmission speeds in networks. The investments and business models of key investors have to be taken into account [16]. 
The gigabit PON (GPON) is well prepared, and the price of GPON devices has decreased. However, newer standards, such as XG-PON or the newest next-generation PON stage 2 (NG-PON2) and Ethernet-based PONs-Ethernet PON (EPON) and 10G-EPON-introduce a new term similar to FTTH. The difference between GPON networks and EPON networks is important because both networks are derived from different backgrounds. GPON was proposed by ITU and employs time division multiplexing (TDM) technology, such as synchronous digital hierarchy (SDH) or the US-equivalent synchronous optical network (SONET). A variant of TDM, which is referred to as a time division multiple access (TDMA) format, is used to allocate time slots to each user to provide downstream bandwidth. TDM technologies such as SDH and SONET (and connection-oriented ATM) are becoming not used in networks due to their complexity and high price. However, an optical transport networks (OTN) is used in core networks and is subject to the reprisal of a software defined network (SDN) because OTN is ITU technology. EPONs are based on the most prevalent networking technology: the Ethernet. EPONs are compatible with other Ethernet devices, such as switches or hubs, and deploying and troubleshooting EPONs are easy because the Ethernet is ubiquitous and well known to many networking engineers. The Ethernet is data link (L2) technology, and Ethernet frames carry IP packets, such as those used for the whole Internet, everywhere.

Another important (perhaps the most important) aspect of EPONs is price-because of massive fabrication of Ethernet chips, 1 Gigabit Ethernet (GE) and even 10 GE are affordable. Some sources indicate that GPONs are 2 times more expensive than EPONs. Other price comparisons are available, but they may be slightly misleading because vendors tend to promote particular technologies, and the GPON/EPON price factor of 10 is most likely exaggerated. The cost of the newest technologies does not allow extensive deployment, and obsolete devices are being replaced by new equipment. This "one by one" strategy is always included in incoming standards for PONs. Two choices are available for selecting an appropriate standard in brownfield or greenfield scenarios. For an incipient ISP, the greenfield scenario is better because it has only fiber infrastructure and no deployed active and passive PON elements (a PON is passive by definition, but active devices are essential and only placed at the end of fibers). An arbitrary standard can be selected for their network. For the brownfield scenario, ISPs operate one standardized technology, and the replacement process becomes more complex. All customers cannot be disconnected at an OLT port during the OLT replacement process because current ONUs will not be able to operate by a new standard; each standard has similar operations but with an additional component of the transmission convergence layer.

\section{PON Progress}

The first idea about the use of completely passive technology was presented in 1980s, when a tree topology was considered for telephony services [11]. The TDMA PON based on telephony focused on transferring telephony services [11]. The main question is this: Why did completely passive technology win? P2P technology offers a higher bandwidth for customers, but P2MP is less expensive per subscriber, and additional passive technology is eliminated:

- Active elements in network and fewer active devices lead to price reduction;

- No requirement for power suppliers or backup battery;

- Exigency optical-electrical-optical conversion for active devices that are not able to process data in the optical domain;

- Total bandwidth reduced due to additional active devices in network (passive technology does not require any other device).

\section{1. $A P O N$}

A passive optical network built on ATM technology represents the first standard of a passive optical network that was approved by ITU in 1998. The entire standard was built on ATM technology and is defined in Recommendation G.983.1 [10]. 
The ATM technology is a networking technology that was adopted in large networks. The reason for using ATM technology was to provide a networking standard for simultaneous transmission of voice and data services. An ATM uses cells as transmission units. The cells were introduced to solve problems/conflicts with networks based on circuit and packet switched technologies. For data transmission, bits and packets are wrapped into a single cell-based data stream.

Cells are data units of constant size (relatively small size). The ATM cell is composed of 53 bytes: header -5 bytes, data -48 bytes. ATM switches can rapidly process cells due to hardware-only-based processing capabilities. The cost of these switches can be very high. Therefore, the use of this particular technology has diminished [17].

ATM networks can provide users with high transfer rates (up to $1.5 \mathrm{Mb} / \mathrm{s}$ to $2.4 \mathrm{~Gb} / \mathrm{s}$ ). Communication can be established using fixed or virtual circuits. ATM networks also guarantee the quality of services for different types of data flows. However, ensure error or device failure detection is not supported [17].

ATM technology was gradually placed in operation in the late 1980s. The initial impulse that resulted in the massive deployment of ATM was the adoption of ATM as a transmission technology for a broadband integrated services digital network (B-ISDN), which was approved by the ITU. The original philosophy of an ATM network was to provide integrated services for an extensive range of applications that will be available to businesses and end-users. At the beginning of the 1990s, this technology was adopted by the computer industry as well; the reason for this was probably the increasing demand for higher bandwidths and support for a variety of multimedia applications [18]. The ATM implementation had the following advantages [18]:

- Infrastructure and interfaces are application-independent;

- Full multiplexing/demultiplexing support;

- Effective handling of both variable and constant bit rates;

- Good support for delay-sensitive multimedia services;

- Simplified network management and operation;

- Promise of future security.

\subsubsection{Historical Development of the APON Standard}

The first testing of this standard in normal operation was realized in the 1990s. Since 1995, an international initiative of telecommunication service providers and a telecommunication equipment manufacturers full service access network (FSAN) has emerged, which has significantly contributed to the development of this technology $[19,20]$. The standardization of ITU organizations, as previously mentioned, emerged in 1998. The implementation of this standard accelerated development in the field of electrotechnical components, the price of which significantly decreased, thereby improving their availability. In 2001, the APON standard became the technology that was considered for deploying FTTH access networks [21].

During development of the APON standard, the FSAN combined two key technologies: ATM and PONs. In the case of access networks based on traditional ATM technology, a static multiplex is used. Multiplexing on the network is provided by access switches that combine a large number of incoming data streams from end-users into one outgoing data stream. However, these elements are active elements that require a power supply. These devices need to be placed on the route between the service provider and the end-user. The cost of maintaining these access switches, with the cost of their power supply, is not a negligible item, thus increasing the total cost of running the access network. In the case of PON implementation, these active access switches are replaced by passive optical hubs [17].

One of the first APON specifications was $155 \mathrm{Mb} / \mathrm{s}$; the maximum hierarchy ratio was set to 32 . This specification involved a maximum of 32 end-users, with full occupancy of the passive optical hub, and the maximum bit rate for one user is approximately $4.8 \mathrm{Mb} / \mathrm{s}$. The first generation would not 
have been a significant improvement; however, it was a symmetric variant that was able to achieve similar transmission speeds as the asymmetric digital subscriber line (ADSL) technology that was expanded at that time. For triple play service (video, voice and data), the first generation would also be inappropriate [22].

In the second generation of the APON, an asymmetric variant was defined. The downstream direction provided users with a transfer rate of $622 \mathrm{Mb} / \mathrm{s}$. The upstream transmission rate remained equivalent to the first generation rate: $155 \mathrm{Mb} / \mathrm{s}$. The maximum splitting ratio was set to 32 . In this particular case (when the hub was fully occupied), the maximum bit rate for a single user was approximately $19.4 \mathrm{Mb} / \mathrm{s}$ (in the downstream direction) [17].

The third generation of the APON was a symmetric variant with a transfer rate of $622 \mathrm{Mb} / \mathrm{s}$, and the maximum split ratio was unchanged compared with the two previous generations [22].

For economic reasons, optical lines were not ended at end-user properties. Multiple end-users were connected to a single ONU reusing an already working metallic network. As a result that downstream data are sent to all ONUs on the network, the number of ONUs that are connected to the optical tree topology was limited to 64. Using this approach, the system's power costs (on the provider's side) can be limited. The typical reach of the APON system was approximately $10 \mathrm{~km}$ [23].

\subsubsection{Access Methods to Shared Media}

Designing an appropriate access method for the APON standard was an initial problem because the total available transmission capacity had to be evenly distributed among all active ONU units. Moreover, the access method should not in any way disrupt the transport profiles of the current ATM technology. Generally, the PON structure is centralized. The main element of this structure is the OLT unit, which does control the allocation of available bandwidth [23].

In 1987, research had already begun on a system applying the TDMA approach. The research was initiated by British Telecom and was conducted at BT Laboratories. This research was conducted on a system known as telephony via PON—telephony over PON (T-PON)—which offered PON telephony services [24-26]. The first system based on the TDMA method was built and tested in real time in 1989. This particular access method has proven to be successful when combined with the promising ATM technology [19].

In the downstream direction (OLT $\rightarrow$ ONU), TDM is used, and in the opposite (upstream) direction (ONU $\rightarrow$ OLT), TDMA is used. In the case of upstream transmission, the ATM is added to the cells that are used to synchronize the power range and the clock.

ATM cells from the end-point network units are merged in the upstream direction at the output of the passive optical hub into the resulting data stream. A collision may occur between two cells that are transmitted in the upstream direction by different sources. For this reason, the TDMA multiplex is used. In the downstream direction, no collisions occur [17].

\subsubsection{Communication in APON}

For frames sent in the downstream direction, (a) basic transfer rate of $155 \mathrm{Mb} / \mathrm{s}$ contains a total of 56 ATM cells (each of the cells is 53 bytes in size); and (b) for $622 \mathrm{Mb} / \mathrm{s}$, the frame contains a total of 224 ATM cells. Two cells are always reserved: physical layer operation and administration and maintenance (PLOAM) messages. The first message is located at the beginning of the frame, and the second message is located in the middle of the frame. The remaining messages contained within the framework are ATM cells that transmit user data $[18,27,28]$.

In the downstream direction, PLOAM messages are used to deliver grants. These grants are continuously transmitted by the OLT unit to all connected ONUs. The grants serve as permits for individual ONUs to transfer user data to ATM cells, which can affect the assigning of bandwidth to ONU units [27].

In the upstream direction, the transfer of frames is a cluster of ATM cells, and each cell contains a 3B header that facilitates cell separation and synchronization in the receiver (PLOAM messages and 
ATM cells). An OLT unit must have these receivers. Additionally, it is important that the OLT unit is able to synchronize with the ONUs that may be located at different distances from the OLT. In the upstream direction, PLOAM messages are used by ONUs to transmit queue size information for the OLT. The OLT can apply this information to allocate the necessary bandwidth.

The structure of the APON frame is shown in Figure 3. The frames sent in the downstream direction vary depending on the transfer speed, while the frames sent in the upstream direction remain the same for the symmetric and asymmetric variants.

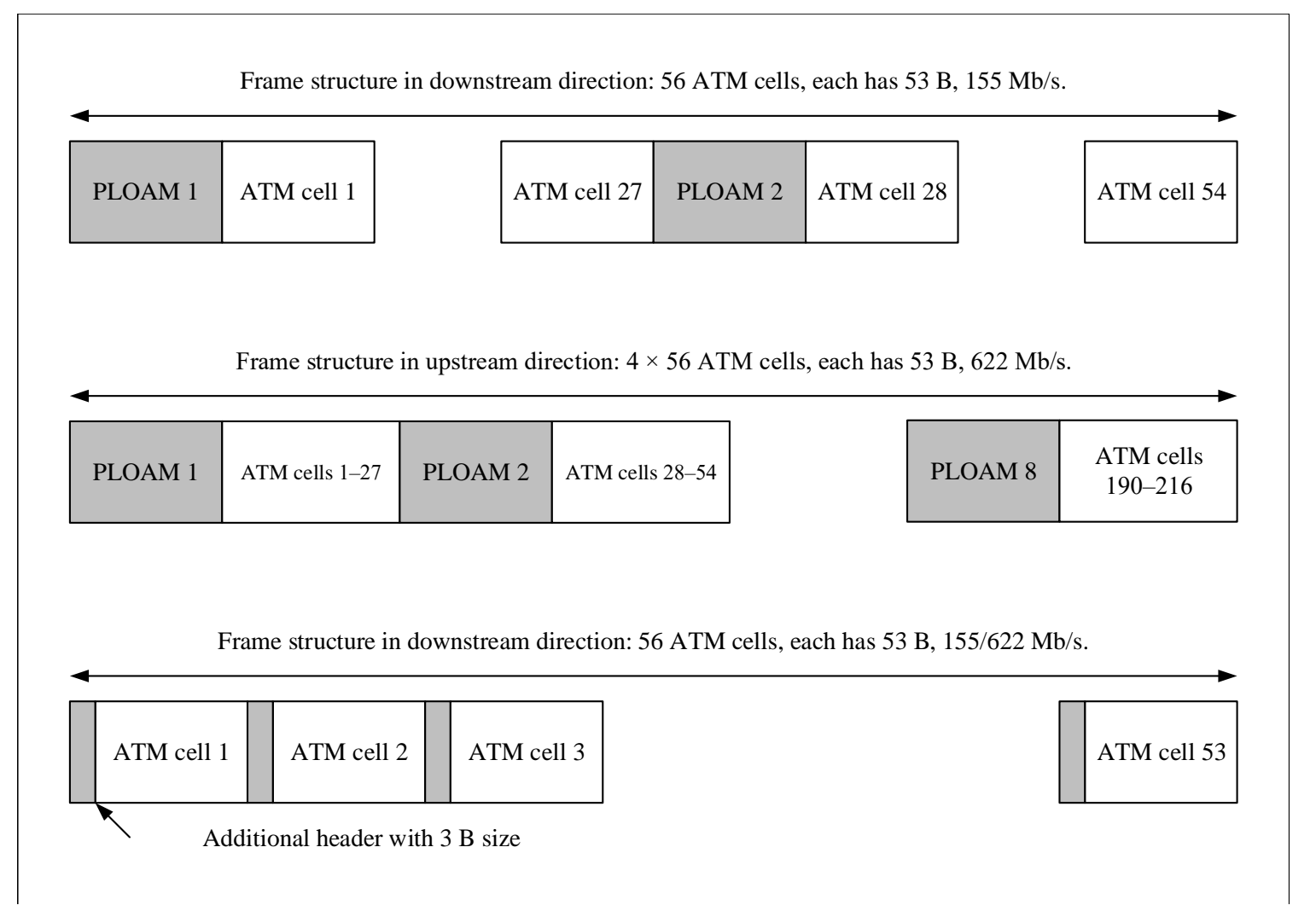

Figure 3. Structure of asynchronous transfer mode passive optical network (APON) frames [10].

\subsubsection{Dynamic Bandwidth Allocation}

In the case of passive optical networks, a point-to-multipoint connection with a central point (OLT), which is superior to all other endpoints, exists. This structure is a hierarchical structure that is typical of tree topologies. Some differences with classical point-to-point connections, such as static bandwidth allocation for a particular connection, are observed. If the static bandwidth allocation for the APON system with a transfer rate of $155 \mathrm{Mb} / \mathrm{s}$ (first generation, symmetric) is used, each of the 32 end-users would have been provided with the transmission rate of $4.8 \mathrm{Mb} / \mathrm{s}$ in both transmission directions.

Dynamic bandwidth allocation (DBA) is based on the idea that all connected end-users do not need the full bandwidth at a given time. The implementation of this mechanism is not a problem in the APON network because the transmission rate is relatively high and the latency-based problems are minimized [22].

In 2001, the ITU issued Recommendation G.983.4 (see [29]), which implements a DBA mechanism and systems based on the original G.983.1, which were not available in the recommendation. The DBA mechanism has three different strategies [22]:

1. Report without status;

2. Status report itself;

3. Hybrid report. 
In the case of report number 1, traffic through the OLT unit is being monitored. If the occupancy of associated queues increases, the unit evaluates this event as a requirement for increasing the bandwidth. In the second case, the ONU reports its state to the OLT. If the ONU requires a higher bandwidth, it sends the request to the OLT. Hybrid reporting involves a combination of the two previous types.

\subsubsection{Deploying APON System}

Various ATM-based passive optical networks were tested [18]:

- 1990: British Telecom (APON);

- 1993: France Telecom (SAMPAN);

- 1993: Nippon Telegraph and Telephone;

- 1993: Siemens;

- 1994: European Commission (Broadband Access Facilities project).

The first commercially available APON system was developed by Alcatel. The system was tested in the following locations [18]:

- 1994: Bermuda, 100 connected entities;

- 1995: Great Britain, 2500 households joined;

- 1996: Belgium, 50 connected entities;

- 1996: France, 100 connected entities.

During the first testing, in 1994, the system provided end-users with plain old telephone service (POTS) and video on demand (VoD). These services were provided for 100 entities (87 households and 13 companies). Individual participants were connected via a passive optical network that was terminated by the ATM subscriber unit (ASM). The connection of these end units was accomplished by the FTTB or FTTH architecture. All users shared a single ASU in the building [30].

The largest test of the APON system was performed in the United Kingdom (UK). A total of 2500 end-users were connected using multimedia services. The participants were connected via the ADSL network using existing metallic lines. A total of 500 ONUs were connected using optical cables and APON technologies. Two cities-Colchester and Ipswich-were interconnected; several broadband switches were used for the connection. These switches were connected to a circle using SDH technology with a transfer rate of $2.4 \mathrm{~Gb} / \mathrm{s}$.

\subsubsection{SuperPON}

At the time of the APON standard development, research on brand-new PON technology had already begun. The research was based on the assumption that the size of access networks would continue to increase. The advanced communication technologies and services (ACTS) research project-named the AC50 photonic local access network (PLANET) - focused on the development of a new PON technology for large networks with a high hub ratio [18].

In March 1997, an optical transmission laboratory test was performed: a large network with a high distribution ratio. In 1998, testing of multimedia transmission on the SuperPON network was conducted in Brussels.

The SuperPON had very ambitious parameters (hypotheses): a maximum reach of $100 \mathrm{~km}$ was considered, and the total hierarchical (hub) ratio was set to 2048. Two transfer rates were supported: $2.4 \mathrm{~Gb} / \mathrm{s}$ (downstream direction) and $311 \mathrm{Mb} / \mathrm{s}$ (upstream direction). The bandwidth was estimated to be sufficient for 15,000 end-users. For a fiber to the cabinet/curb (FTTC) or FTTB architecture, connecting even more users would be possible [31].

The SuperPON technology should be based on ATM cell transfer. However, optical amplifiers are necessary. It was suggested that the erbium-doped fiber amplifier (EDFA) should be used for the downstream direction. In the case of the upstream direction, a semiconductor optical amplifier (SOA) 
should be used. The reason for using the SOA amplifier was the need for rapid switching to reduce the level of the associated noise [31].

\subsection{BPON}

Broadband PON (BPON) is the second standard of PONs defined by the ITU and is defined in Recommendation G.983.3 [32]. The approval of this recommendation in 2001 caused the implementation of the wavelength division multiplex (WDM) and contributed to the use of multiple existing optical transmission paths. The BPON standard is based on the previous APON standard (backward compatible) and applies the same transfer rates for transmission. The main benefit of the new standard was the introduction of the WDM to passive optical networks [33].

The principle of a wavelength multiplex is the use of different wavelengths for transmission in an optical fiber. Various optical signal sources radiate at different wavelengths. The advantage of this solution is the ability to connect multiple channels to a single optical fiber; otherwise, these channels would have to be separately transmitted $[34,35]$.

WDM is a hybrid multiplex that is very promising in terms of usage of the transmission capacity of an optical fiber. WDM technology is most similar to frequency-division multiplexing (FDM). For FDM, transmissions occur at different frequencies. For WDM, transmissions occur at different wavelengths. At the beginning of an optical path, signals from multiple transmitters must be merged to a single optical fiber. For this purpose, a multiplexer/demultiplexer pair is used [34,35].

\subsubsection{Historical Development of the BPON Standard}

The BPON standard has enabled several improvements over its predecessor. The division of traffic into classes has been expanded by voice services, in particular, services of classical telephony and voice over Internet protocol (VoIP). The spectrum of wavelengths for the downstream direction was divided into two bands. The first band was used for existing BPON protocols, and the second band was intended to be reserved for video services transmission [36]. With the BPON standard, one or two optical fibers could be used for transmission. In the case of a single fiber, wavelengths of $1310 \mathrm{~nm}$ and $1550 \mathrm{~nm}$ were used for the downstream direction and upstream direction, respectively $[37,38]$. When two optical fibers (the first fiber for downstream direction, the second fiber for upstream direction) were utilized, a wavelength of $1310 \mathrm{~nm}$ was used [22].

The ITU has allocated a new band of wavelengths between 1500 and $1550 \mathrm{~nm}$ for WDM. The wavelength of $1550 \mathrm{~nm}$ was used for video signal transmission [39]. For a wavelength multiplex, wavelengths used for the transmission of a single optical fiber were modified. For the downstream direction, a wavelength of $1310 \mathrm{~nm}$ was selected. For the upstream direction, a wavelength of $1490 \mathrm{~nm}$ was used [22].

DBA was standardized in G.983.4 [29] and enabled increased transmission capacity in the upstream direction [36].

Gradual deployment of the BPON network has reached its peak. With the new millennium, the area of digital video has been developing. The highest possible speed of the BPON standard $(622 \mathrm{Mb} / \mathrm{s})$ would be insufficient for high-definition digital signal transmission, especially when this speed is split among 32 end-users. The development of passive optical networks has focused on new standards that can provide higher transmission rates and the possibility of connecting multiple endpoints [36].

\subsubsection{Deploying the BPON System}

Testing of BPON was conducted in 1999 by the American company BellSouth. In total, 400 of subjects from the suburbs of Atlanta were connected. In this test, end-users were provided with triple play services; $\mathrm{VoD}$ was distributed over a separate optical cable; and the reception was realized via the optical network termination (ONT) video unit. For high-speed Internet and telephone services, another ONT unit was used. The deployed BPON system was operated at wavelengths of $1490 \mathrm{~nm}$ 
(downstream direction), $1310 \mathrm{~nm}$ (upstream direction) and $1550 \mathrm{~nm}$ (video signals). An asymmetric variant with a speed of $622 \mathrm{Mb} / \mathrm{s}$ in the downstream direction and a speed of $155 \mathrm{Mb} / \mathrm{s}$ in the upstream direction was deployed [39].

In 2002, networks based on the BPON standard were built in Japan. In 2004, Verizon joined more than a million households with the BPON [39].

Over the course of 2001, the Institute of Electrical and Electronics Engineers (IEEE) developed a new EPON of standard passive optical networks, creating strong competition due to the acquisition costs of ATM switches, which are relatively high compared with the acquisition costs of Ethernet switches. The same condition is true for network cards and other components. The EPON standard is prevalent in Asia, most notably in China, Korea and Japan [19]. In 2005, the EPON standard became the dominant PON technology in Japan [40].

\subsection{GPON}

The GPON is a standard defined by the ITU organization, namely, Recommendation G.984. The first recommendation, Recommendation G.984.1, which describes the basic characteristics of GPON networks, was approved in 2003 [41,42]. The GPON standard supports all currently known telecommunication services.

The development of new passive optical network standards has been driven by ever-increasing bandwidth demands. The ATM technology on which the two previous PON standards were based has not substantially expanded.

A major drawback of this technology is the lack of support for broadcasting. A multicast connection was possible by the ATM. The principle of a multicast connection is based on the existence of a data source that only broadcasts to subscribers who are interested in the broadcast and are registered in a particular multicast group. Via this multicast group, the subscribers are authorized to receive data from a specific source. However, ATM technology did not support broadcasting from multiple sources. Broadcasting could be implemented via multicast, where the recipients were nodes in the network [17].

During the GPON design, support for ATM technology was also standardized (for backward compatibility with the BPON). The use of ATM was gradually abandoned (2014). However, the introduction of a new GPON encapsulation method (GEM), through which it is possible to encapsulate frameworks of various transmission technologies (most often Ethernet frames), represents a significant step forward [36]. However, the GPON standard is not compliant with EPON, which is based on Ethernet technology [43]. Development of the standard was also affected by the providers of telecommunications services, which demanded that their deployed devices be gradually modernized. The problem was, however, that BPON and GPON could not be deployed within a single optical network since BPON is available for transmission at different wavelengths. However, building a new infrastructure parallel to the existing telecommunications infrastructure would be too costly economically. Similarly, replacing all ONUs located at end-users or temporarily shutting down the existing telecommunication network would be technically difficult. Therefore, GPON wavelengths have been reserved to enable the gradual deployment of the new generation of PONs. Introducing filters into ONUs was important; these filters were designed to block a certain wavelength to enable a smoother transition to new technology. Greater scale implementation of GPON technology occurred in 2008 and 2009 [36].

With an expansion of IP and VoD services, an increase in the number of end-users was observed. However, the willingness of end-users to pay for higher bandwidth was not very high. Therefore, a compromise was needed to satisfy the needs of end-users (customers) and service providers. Consequently, the introduction of passive optical technology on access networks has begun [40].

PONs have expanded in Asia; in 2004, the number of end-users connected through a PON was approximate $93 \%$ (1.4 million end-users). In 2004, 84\% of end-users were connected in Asia through a BPON, and the remaining $16 \%$ were EPON-competing. The second continent of expansion, 
where the PON network was deployed in a wide area, was North America, especially the United States, where the number of end-users connected by $\mathrm{BPON}$ was approximately $81 \%$, and the remaining $19 \%$ was EPON technology.

The gradual deployment of GPON began in 2006, when the standard started to gradually replace its predecessor BPON [40].

The GPON standard provides new transmission speed ranges. In the downstream direction, 1244 or $2488 \mathrm{Mb} / \mathrm{s}$ can be used, and 155, 622,1244 and $2488 \mathrm{Mb}$ /s are supported in the upstream direction [41]. These speeds can be combined. The most common option is an asymmetric variant with a downstream rate of $2488 \mathrm{Mb} / \mathrm{s}$ and an upstream rate of $1244 \mathrm{Mb} / \mathrm{s}$. With previous standards, speeds of 155 and $622 \mathrm{Mb} / \mathrm{s}$ are supported; thus, backward compatibility is maintained [43].

The following wavelength ranges are reserved for the transmission: (a) in the downstream direction, the range is 1480 to $1500 \mathrm{~nm}$, and (b) in the upstream direction, the range is 1260 to $1360 \mathrm{~nm}$. For the transmission of video signals, an additional range of wavelengths from 1550 to $1560 \mathrm{~nm}$ can be applied [43].

A double increase in the splitting ratio exists. GPON-based networks can use a ratio of 1:64, with a ratio of 1:128 planned for the future. The logical reach of the GPON network is $60 \mathrm{~km}$, and the physical reach of the GPON network is 10 or $20 \mathrm{~km} \mathrm{[41].}$

\subsubsection{Communication in GPON}

The GPON standard uses the GEM encapsulation method to encapsulate different data types [43].

The frames are broadcast in the upstream direction and travel to all end units. The TDM is used for the downstream direction, such as the BPON standard. However, each of the end units must only accept frames that are intended for the end unit, which is ensured by the unique identifiers that are contained within the frame. Therefore, the data are processed only by the unit for which the data were determined.

Frames in the downstream direction are composed of a physical control block downstream (PCBd) that is tracked by a portion reserved for the ATM cell and a portion reserved for the GEM. The length of the PCBd header is the same size for all transmission rates. If no data are requested for sending, the frames are forwarded in the downstream direction; the PCBd is also used for time synchronization [44].

In the upstream direction, such as the BPON standard, TDMA techniques are used. By using this technique, OLT assigns variable time intervals to ONUs. The intervals are primarily used to synchronize the clustering of data that are transmitted in the upstream direction to the ONUs [43-47].

The forward error correction (FEC) technique is an important improvement. Using the error correction, an error in the transmission can be both detected and immediately repaired. FEC adds redundant information to the encoded bit sequence; however, the size of the added information is minimal, and the overhead associated with data transmission has not increased. If a higher FEC value is applied, a decrease in the transmission rate can be accomplished [43]. The structure of GPON frames in ascending and descending directions is shown in Figure 4. 
Frame in downstream

\begin{tabular}{|c|c|c|c|c|c|}
\hline PCBd 1 & Payload & PCBd 2 & Payload & $\operatorname{PCBd} n$ & Payload \\
\hline
\end{tabular}

Frame in upstream

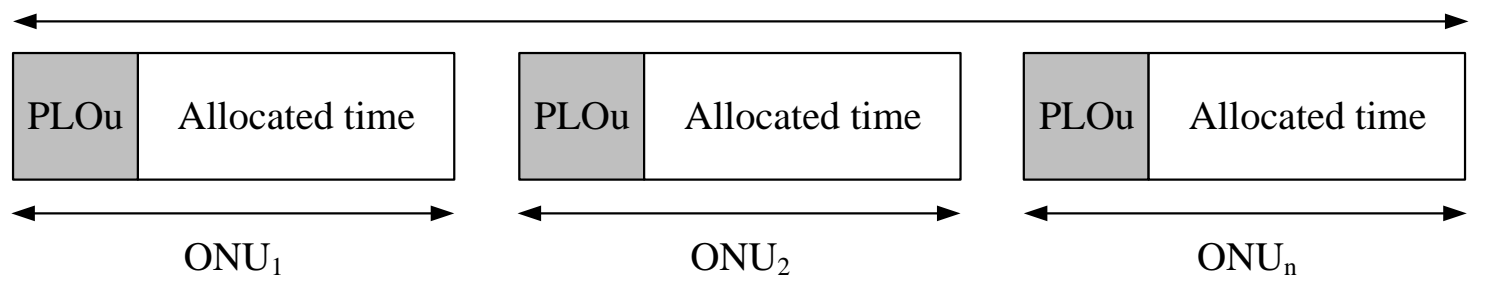

Figure 4. Structure of gigabit passive optical network (GPON) frames [29].

\subsubsection{Dynamic Bandwidth Allocation}

For bandwidth allocation in the upstream direction, transmission containers that are labeled as a transmission container (T-CONT) are used. The benefit of using these containers is the improved usage of the total bandwidth because the ONU can use one or more of these containers during communication. The containers enable the implementation of the quality of service (QoS) in the upstream direction. A total of five types of transport containers for different purposes are defined. The containers serve multiple purposes [43,44]:

1. Guaranteed fixed bandwidth for services sensitive to delay (VoD, VoIP);

2. Guaranteed fixed bandwidth for services insensitive to delay (data transfer);

3. Combination of fixed and dynamically allocated bandwidth (triple play services);

4. Dynamic bandwidth allocation, the allocation is not guaranteed (best effort);

5. Combination of all previously mentioned purposes.

The allocation of the available bandwidth for each ONU terminal unit is performed again by the OLT unit. Bandwidth allocation occurs only in the upstream direction; in the downstream direction, the data are transmitted in every direction for all terminal units.

To determine the required bandwidth, OLT uses the information contained in the T-CONT transport container that is assigned to a particular ONU. The transport container holds information about the number of data units contained in the cache of the respective ONU. This information is evaluated by the OLT unit, which can reallocate grants for the ONU terminal units. If the ONU does not have any data to send, it only sends an empty data unit after receiving the grant. This state indicates an empty cache of the ONU; thus, OLT may provide a grant to another ONU. If the ONU has a full cache, the OLT can provide the ONU with multiple grants [43].

\subsubsection{Deploying the GPON System}

In 2006, 20 years after the launch of the first PON test network, preparations for optical access network (OAN) implementation were launched in France. Various French telecommunication service providers started to connect end-users via FTTH. In early summer 2006, France Telecom launched the testing of high-speed GPON-based connections. The system was tested in six Paris neighborhoods and, to a lesser extent, in surrounding cities. Optical fiber was fed to end-user households (FTTH), and several hundreds of households were connected [19].

Another test of the GPON was Deutsche Telekom's testing in Germany. Testing was conducted in Berlin and Potsdam. The main purpose was to test the GPON and new laying techniques. In these 
cities, laying was performed by plugging an optic cable into a previously placed sheath. At the last mile, optical fibers for individual end-users were blown into microducts to realize the FTTH. A total of 9 institutions were connected. The end-users were equipped with ONT units that had $100 \mathrm{Mb} / \mathrm{s}$ ports at their disposal [48].

Another city where the GPON system was tested by Deutsche Telekom was Dresden. Nearly the entire city was connected via very-high-speed DSL (VDSL); however, FTTC terminals were previously used. An advantage was that an optical line had been installed in the part of the city that was selected for testing the GPON system in the early 1990s. These terminals were used by the HYTAS94 optical system by which telephone services (POTS and ISDN) were operated. However, this system has not been able to provide adequate transmission rates for triple play services. Therefore, the system has not been standardized or further developed.

Following the experience of the GPON test in Berlin, in 2008, Deutsche Telekom decided to test the system in Dresden, Germany. A total of 3500 buildings with a total of 27,000 households were connected. In large buildings, the connection was realized by FTTB. In the cellars, ONU units were placed and consequently used for connecting end-users by existing metallic lines. Ending FTTH was used only for the smallest buildings, typically family houses [48].

\section{4. $X G-P O N$}

Next-generation PON (XG-PON) is the next category of the ITU-defined standards in Recommendation G.987. G.987.1 [49]; the first recommendation in this set of standards describes the basic characteristics of the XG-PON network and was approved in 2010 (the first version). The standard is sometimes referred to as 10G-PON, where $X$ is a Roman numeral that indicates a transmission rate of $10 \mathrm{~Gb} / \mathrm{s}$.

As soon as the GPON standard was expanded, FSAN logically turned its attention to the successor to the successful GPON standard. Since 2007, preparations have been underway to develop a new generation of passive optical networks led by FSAN together with the ITU. Their primary objective was to define the requirements for the next-generation PON, which was completed during 2009 [36,50,51].

As a result of this study, the XG-PON standard was defined in the previously mentioned set of G.987 recommendations that was established. The XG-PON standard adopted many features from the previous GPON [52].

\subsubsection{History}

One of the main requirements for the development of new passive optical network standards is to ensure a higher bandwidth for end-users compared with previously used standards. An important requirement is to ensure a smooth transition to the new PON technology, both for service providers and end-users [53].

Most of the performed studies indicate that the demand for higher bandwidth continues to increase (6-10 $\times$ every 6 years) and is unlikely to stop [54]. The increase is caused by the ever-increasing amount of television and other video services running on the Internet. In the future, we can expect a further increase as the number of devices that support these services increases, particularly television sets and mobile devices. In the case of televisions, their resolution and the resolution of the video is also increasing, which substantially affects the bandwidth required for the transmission [54].

Another important milestone in this area was the approval of G.984.5, which extended the specification of the current GPON standard. The primary objective of the recommendation was to enable the simplest possible transition from GPON to a newly developed standard. The wavelengths and a special WDM element that ensures that two different standards collaborate were reassigned. New end-unit filters that block certain wavelengths were also defined. Their goal is to prevent undesirable interactions in the common functioning of two generationally different standards [55]. 


\subsubsection{Next-Generation PON}

During the development of the new generation of passive optical networks, which are known as the next-generation PON (NG-PON or XG-PON), this development was divided into two subgenerations-NG-PON1 and NG-PON2-depending on the possibility of joint operation with older PON standards on a common network infrastructure [53]. The NG-PON study considered the development and deployment of a new standard from 2012 to 2015 (NG-PON1). Technologies that were not suitable for implementation during this period were included in the NG-PON2 study [54].

In the case of NG-PON1, a support with the GPON standard coexistence within the same ODN is guaranteed. The advantage of this coexistence is that switching to a new standard can be easily achieved without the need for major interventions in existing network infrastructure and without disruption of the functionality of existing end-user services. When selecting a suitable method to ensure the coexistence, the use of TDM or WDM was considered. WDM was selected for both downlink and uplink [56]. The WDM filter, which is used to merge/filter split wavelengths of individual signals (GPON and XG-PON, video signals occasionally) has been introduced. This filter is used to connect the OLT units of both standards with the ODN [49]. An example of the possible coexistence of two different PONs is provided in Figure 5. The assumption of the coexistence is that the ONUs contain filters that perform filtration of the appropriate wavelength depending on the actual PON standard.

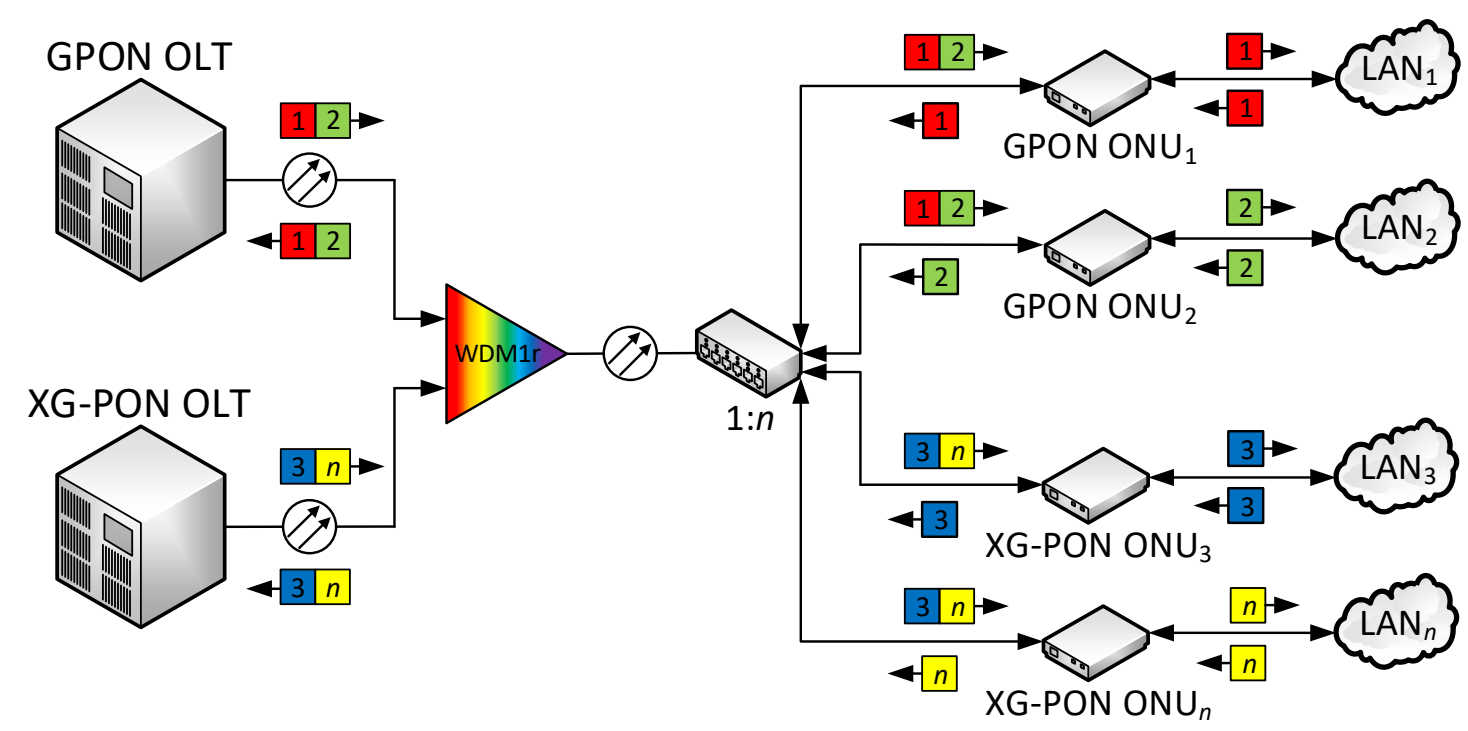

Figure 5. Coexistence scheme of GPON and next-generation PON (XG-PON).

The new generation NG-PON1 requirements focused on the connection of a larger number of users, better QoS and security [53]. For the NG-PON1, several possible variants were considered: TDM-PON, WDM-PON, code division multiple access PON (CDMA-PON) and a combination of these technologies. However, the problem was the difference among the different solutions in their architecture and service profile [56]. Due to its simplicity and possibility for future cost-effective deployment, 10 the Gigabit PON variant based on the TDM access method was selected [54].

In contrast to the previously mentioned facts, the second generation of passive optical networks of the new generation NG-PON stage 2 (NG-PON2) contained systems that were not backwards compatible with older standards. This finding was attributed to the need to build a new distribution part of the ODN or the need for new technologies; however, they were not available in the short term [56]. 


\subsubsection{XG-PON1 and XG-PON2}

As the best candidate for NG-PON1, a system named XG-PON [57] was selected. In general, XG-PON is further divided into XG-PON1 and XG-PON2; the difference is based on the supported transfer rates [54]. The XG-PON1 supports a downlink transfer rate of $10 \mathrm{Gbps}$ and $2.5 \mathrm{Gbps}$ in the upstream direction, whereas the XG-PON2 is a symmetric system that supports a $10 \mathrm{~Gb} / \mathrm{s}$ bandwidth in both directions. For the XG-PON2, the next-generation symmetrical PON (XGS-PON) is also used, emphasizing its symmetric nature [58]. The reason for this division is primarily economic. The symmetrical variant is more expensive, and the market has not experienced considerable demand for this solution; therefore, its development has been temporarily suspended [36].

A wavelength range of 1575 to $1580 \mathrm{~nm}$ is used for the downstream direction, and a wavelength range of 1260 to $1280 \mathrm{~nm}$ is employed for the upstream direction. The ratio of 1:64 is the minimum splitting ratio to ensure the coexistence of the GPON and XG-PON standards. The system supports a splitting ratio of 1:256 (with the extension planned) has to support transmission at a minimum distance of $20 \mathrm{~km}$; the maximum possible distance is $60 \mathrm{~km}$ [49].

During the development of the XG-PON standard, several possible options for wavelengths allocation were considered to ensure the previously mentioned coexistence of the standards. The choice of the appropriate wavelength for the downstream direction was relatively easy. The band approximately $1578 \mathrm{~nm}$ was considered. This step was consistent with the choice of wavelength when developing 10 Gigabit EPON (10GEPON), which was created under the header of IEEE. On the other hand, the choice of a suitable wavelength range for the upstream direction was not an easy task. Four options were considered [56]:

- $1595-1615 \mathrm{~nm}$ : this range was rejected. The reason for this was the concern for the lack of specification of optical fibers and PON components for the associated wavelengths;

- $1540-1560 \mathrm{~nm}$ : this range was also rejected. The reason for this was incompatibility with the overlay video signal. Moreover, this range is used in most of the implemented PONs around the world;

- 1530-1540 nm: the reason for rejecting this range was the cost of ONU units' acquisition for this particular range of wavelengths, as well as the fact that existing ONUs based on GPON technologies are unable to block this range;

- 1340-1360 nm: if this range is selected, a "coexistence" filter would be required. Nevertheless, such a filter would considerably increase the attenuation of the entire PON. For this reason, this particular range was also rejected.

NG-PON2 networks based on time and wavelength division multiplexing (TWDM) use various ranges for the upstream direction: wideband option 1524-1544 nm, reduced band option 1528-1540 nm and narrow band option 1532-1540 $\mathrm{nm}$.

Another necessary decision was related to the selection of link speed and encoding. The choice between standardized and commercially used SDH solutions and Ethernet solutions had to be made. At this selection point, the following question arose: Since the use of WDM enables coexistence with EPON systems $(1 \mathrm{~Gb} / \mathrm{s})$, can the XG-PON standard coexist with the 10GEPON standard? If this complex coexistence is required, Ethernet is the logical choice. However, the coexistence of different generations of different types of systems will not be necessary because the service providers unlikely simultaneously deployed XG-PON and 10GEPON to a common network infrastructure [56].

XG-PON's innovative features include energy saving measures. In the event of the failure of a primary power supply, and if the OLT is powered from a backup power source (typically, a battery), the aim is to reduce the unit load to enable the battery to power the unit for a longer period of time. When powering from the primary source, the effort is to reduce the power consumption to the lowest possible value. One option is to disable a user-defined network interface that is not actively used. Another option is to deactivate the transmitter if the user does not have any data to be sent (dozing). 
In the case of an inactive user, the ONU deactivates its transmitter and receiver (sleeping); the latter solution then displays the highest energy savings [56].

\subsubsection{Communication in XG-PON}

The XG-PON standard is based on its predecessor GPON; therefore, both of these standards have a common features. In addition, the XG-PON standard generates certain improvements. The principle of communication in XG-PON is the same as that in previous standards. The XG-PON frames consist of the XG-PON transmission convergence (XGTC) header and a part dedicated to useful data. In the descending direction, the XGTC header is composed of three additional parts [59]:

1. Fixed-size part, which contains information about the length of the following parts of the header. It is ensured by header error correction (HEC);

2. Bandwidth map (BWmap) is used to hold information about the allocated bandwidth for the given ONU unit;

3. The last part is for dedicated transmission of PLOAM messages.

Compared with the GPON standard, frames sent in the downstream direction can contain more than one PLOAM message. Based on the previously mentioned methods for energy consumption regularization, an advantage is better channel response. The size of the PLOAM was increased. In the cluster of data that is sent in the upstream direction, different kinds of headers exist. At the beginning of the data cluster, a headline with fixed and variable size exists. The former contains the ONU's identification number. This identification number is expanded to the XG-PON standard to support a larger splitting ratio (maximum of 1023 endpoint units are supported). The variable-sized header contains the PLOAM message sent in the upstream direction (if it was sent). Additionally, an optional header for transmitting a dynamic bandwidth report upstream (DBRu) message may be included $[56,60,61]$. The XG-PON frames are shown in Figure 6.

Frame structure in downstream

\begin{tabular}{|c|c|c|c|c|c|}
\hline $\begin{array}{c}\text { XGTC } \\
\text { header } 1\end{array}$ & Payload & $\begin{array}{c}\text { XGTC } \\
\text { header } 2\end{array}$ & Payload & $\begin{array}{c}\text { XGTC } \\
\text { header } n\end{array}$ & Payload \\
\hline
\end{tabular}

Frame structure in upstream

\begin{tabular}{|l|c|c|c|c|c|c|c|}
\hline $\begin{array}{l}\text { XGTC } \\
\text { header }\end{array}$ & DBRu & Payload & DBRu & Payload & DBRu & Payload & $\begin{array}{c}\text { XGTC } \\
\text { trailer }\end{array}$ \\
\hline
\end{tabular}

Figure 6. Next-generation passive optical network (XG-PON) frame structures for both directions.

Similar to the GPON standard, the GEM encapsulation method is used in the XG-PON standard; it is referred to as the XG-PON encapsulation method (X-GEM). This method performs three main tasks [59]:

1. Traffic marking through a 16-bit ID;

2. Fragmentation;

3. Ensuring privacy for transmitted data.

During fragmentation, the transmitted data units can be divided to enable the first part (fragment) to be transmitted in the current frame and its second part to be transmitted at the next opportunity. Fragment creation rules were modified to avoid the creation of fragments that were too small [56]. 


\subsubsection{Deploying of XG-PON System}

One of the first XG-PON tests was conducted in 2009 by Verizon in Taunton. Verizon has deployed passive optical networks since 2004, when BPON-based networks were deployed.

The aim of the test was to verify the capability of XG-PON and GPON to simultaneously work on a common network infrastructure and the ability of the XG-PON technology to achieve a maximum of a fourfold increase in bandwidth in the downstream direction. During the test, the XG-PON optical signal was overlaid onto an existing GPON network.

On the service provider side, the OLT XG-PON technology unit was installed during the test. This unit was the prototype of XG-PON1, which was manufactured by Huawei in advance of the standard approval. Therefore, transfer speeds of $10 \mathrm{Gbps}$ in the downstream direction and $2.5 \mathrm{~Gb} / \mathrm{s}$ in the upstream were supported. Using the WDM, the optical signal of the XG-PON and GPON technology were combined with the optical signal that provided the video services transmission. Video services were distributed both on the XG-PON ONT unit and the GPON ONT unit. The existing GPON OLT unit, with the newly installed XG-PON OLT unit, was connected to borderline routers via Internet routers.

Existing GPON ONT units were equipped with wavelength blocking filters utilized by XG-PON technology; specifically, the band range of 1575 to $1625 \mathrm{~nm}$ was reserved for the downstream direction. For the upstream direction of the XG-PON technology, a wavelength range of 1260 to $1280 \mathrm{~nm}$ was used. For this reason, the original range of the GPON for the upstream direction was limited to 1290 to $1330 \mathrm{~nm}$. A special WDM1r part that ensured that the XG-PON and GPON wavelengths merge and their subsequent transmission over a common fiber was also needed. A similar part was used by Verizon for the coexistence of BPON and GPON [54].

On the end-user side involved in this test, a passive optical hub with a 1:2 splitting ratio was installed to divide the optical signal between the XG-PON unit and the GPON ONT unit. This division enabled monitoring of the possible impacts of the coexistence of these two technologies. Separate monitoring of the behavior of each of the technologies was possible.

The XG-PON system was able to deliver a transmission rate of $9.868 \mathrm{~Gb} / \mathrm{s}$ in the downstream direction and $2.398 \mathrm{~Gb} / \mathrm{s}$ in the upstream direction despite the presence of the GPON signal [54].

Before actual field testing, the prototype of the XG-PON system was tested in Verizon's laboratories. This testing was primarily focused on the physical layer. The prototype passed the tests. This prototype also enabled flawless data transmission to a maximum distance of $60 \mathrm{~km}$.

Testing of the XG-PON technology was successful, and no impact on the coexistence of XG-PON and GPON technology was demonstrated on a common infrastructure. This finding enabled service providers to smoothly move from GPON technology to XG-PON technology without a significant effect on existing end-users [54].

The XG-PON2 will not be deployed in the future. The IEEE has standardized the 10GEPON standard, which has a transmission rate of $10 \mathrm{~Gb} / \mathrm{s}$ in both directions. Providers of telecommunication services could prefer this standard, and the ITU could start working on the development of the next-generation PON [36].

\subsection{NG-PON2}

A recent PON standard under the header of the International Telecommunication Union is a standard named NG-PON2. This standard is defined in Recommendation G.989. The first recommendation G.989.1 describes the basic requirements for the new system and was approved in 2013 [62].

\subsubsection{History}

NG-PON2 originally did not contain any requirements to ensure coexistence with older PON standards. NG-PON1 and NG-PON2 were planned to be independently standardized in 2010. 
However, the development of the new standard was delayed due to the decline of telecommunication services operators' interest in the new PON architecture and a slowdown in the market, which affected the investment of service operators in access networks. Current standards, which are based on the TDMA access method, are not consistent with ever-increasing bandwidth requirements. NG-PON2 did not have a preferred technology at this time, and a choice among TDMA-PON, WDM-PON, orthogonal frequency division multiplex PON (OFDM-PON) and code division multiple access PON (CDMA-PON) was considered [53]. It was very likely that the WDM-PON variant would be selected [36]. The requirements for the next-generation PON were described as follows [63]:

- High financial efficiency;

- High capacity;

- Great reach and wide coverage;

- Effective allocation of network resources;

- Competitiveness;

- High energy efficiency.

Below is a brief description of the variants considered for NG-PON2 [63]:

TDM/WDM-PON: a hybrid variant that takes advantage of TDM (flexible bandwidth allocation) and WDM (especially high capacity). This variant is further subdivided according to the method of wavelengths' allocation to individual end units. In the case of a static variant, the wavelengths for upstream and downstream direction are assigned to the ONUs and cannot be changed during operation. On the other hand, dynamic variation is possible to dynamically change the wavelengths depending on the associated data traffic.

WDM-PON: as the name suggests, this option is used to transmit data using the wavelength multiplex. Each end-unit ONU has assigned a different wavelength (for both downstream and upstream direction) for communication with OLT.

OFDM-PON: uses the OFDM method. The OFDM principle is based on the division of the broadband signal into many low-bandwidth subcarriers. Subcarriers have partial spectral overlap, but they are unaffected by one another. They can be modulated by higher-order modulation formats to reduce bandwidth requirements. In the downstream direction, high bit rates are achieved by OFDM, and in the upstream direction, multiple access control is applied.

CDMA-PON: in this variation, different codes are used to communicate between OLT and ONU. At first, the codes are assigned to individual users, next data of these users are coded into the pulse sequences (or decoded from these sequences) using the allocated codes. The undeniable advantage of CDMA-PON is greater security.

With PONs based on high-bandwidth TDMA, reducing the sensitivity of the receiver would be a prerequisite. In addition, increasing the number of ports is necessary for connecting multiple end-users. In the WDM PON, a problem with the use of suitable end-user devices was selective to a certain wavelength. Despite the rapid advances in the field of receivers for ONU units for use in WDM PON networks, these receivers were considerably more expensive than TDMA-PON receivers. The WDM-PON solution has not satisfied the requirements of financial efficiency.

The CDMA-PON systems were only needed at the research stage, and the bandwidth allocation mechanisms had to be addressed. Another problem was the lack of maturity and the lack of optical encoders and decoders for this PON technology [63]. However, with an increase in access network transmission speeds via the introduction of new standards to the operation and an increase in access network transmission capacity, sufficiently dimensioned transport networks are necessary [53].

Other systems from which an additional standard can be created in the future include, for example, OFDM-PON or a coherent PON. In the future, these solutions can satisfy the requirements for a very high transmission capacity, higher separation rates and higher coverage. These solutions would fall into the next-generation PON [63]. 
A similar commitment, such as that of the Czech Republic and the European Union (to ensure a $30 \mathrm{Mb} / \mathrm{s}$ transmission rate for all residents and $100 \mathrm{Mb} / \mathrm{s}$ for at least $5 \%$ of the population and all new customers by 2020) [64], has been adopted by the United States. In 2009, the program "Connecting America: The National Broadband Plan" was launched. The goal of the program was to ensure a transmission speed of $100 \mathrm{Mb} / \mathrm{s}$ in the downstream direction and a transmission speed of $50 \mathrm{Mb} / \mathrm{s}$ in the upstream direction for 100 million US households. In addition, a $1 \mathrm{~Gb} / \mathrm{s}$ connection rate for local communities was envisaged [57].

The logical requirement for the next-generation $\mathrm{PON}$ is to provide better transmission parameters than existing PON standards in the context of increasing bandwidth requirements. The NG-PON2 system must support $40 \mathrm{~Gb} / \mathrm{s}$ (as a result of the wave assignment) in the downstream direction and $10 \mathrm{~Gb} / \mathrm{s}$ in the upstream direction. The NG-PON2 range must be $40 \mathrm{~km}$ (passive infrastructure); the total distance is set to $60 \mathrm{~km}$ [62]. NG-PON2 uses newly allocated wavelength bands: for the downstream direction, the range of 1596 to 1603 is allocated; a range of 1524 to $1544 \mathrm{~nm}$ is allocated for the upstream direction [65].

An important step is the implementation of the "uncolored" ONUs, which are not designed for a specific wavelength. The price of end units is also an important parameter, and this solution also makes it easier to manage endpoints because only one type exists in the network [62]. In addition, the high cost of endpoints can be an obstacle to additional PON deployment. Thus, colorless ONUs will ensure a wavelength-independent operation [57].

In addition, NG-PON2 is expected to be a multipurpose infrastructure that will enable the merging of various telecommunication services and satisfy the requirements of new services. For this reason, the NG-PON2-based network is easily extended. With an increasing share of mobile networks and increasing demands on their transmission capacity and speed, the requirements for this kind of access network must be satisfied. NG-PON2 appears to be a promising solution [66].

\subsubsection{Coexistence}

The original provision that NG-PON2 will not support coexistence with previous PON standards was eventually abandoned [57]. The original assumption of the FSAN organization was that ODN would use arrayed waveguide gratings (AWG) instead of standard optical power splitters, and therefore, coexistence would not be possible. The cost of building an entirely new network infrastructure is high; thus, NG-PON2 should be compatible with the established ODN [66]. One of the requirements for NG-PON2 is to protect ODN investments by ensuring seamless end-user migration to the new system. The new wavelength division takes the coexistence requirement into account and supports the transmission of video signals at separate wavelengths (e.g., for television broadcasting) and in previous standards. Two scenarios [62] were defined for the transition to NG-PON2:

1. Brownfield migration scenario;

2. Greenfield migration scenario.

In the case of the first scenario, passive optical infrastructure was built, and one of the previous PON standards was established. This existing infrastructure will then be used to progressively move to the next generation of PONs. Another option is an immediate transition to a new standard, but in this case, running the older PON system is more appropriate because the end-user units can be time-consuming. For this reason, existing end-users must switch to the new standard as soon as possible. NG-PON2 must be able to support all services provided by older standards, including GPON, XG-PON1, EPON and 10GEPON [62].

The second scenario describes a situation where the network infrastructure is built "greenfield" design) or the existing network infrastructure is reconstructed (e.g., replacing the existing metallic network). In this scenario, coexistence does not have to be taken into account [62]. 


\subsubsection{Communication}

For communication over TWDM, four bidirectional $\lambda$-channels are employed. Each of these channels has a transfer rate of $10 \mathrm{~Gb} / \mathrm{s}$ in the downstream direction and a transfer rate of $2.5 \mathrm{~Gb} / \mathrm{s}$ in the upstream direction. Transmission can be achieved in the case of NG-PON2 technology ( $40 \mathrm{~Gb} / \mathrm{s}$ - downstream direction, $10 \mathrm{~Gb} / \mathrm{s}$ - upstream direction). As a result, further development and usage of the original XG-PON1 standard ensued. Use of the $\lambda$-channels increased the transmission capacity [66].

NG-PON2 also allows us to use overlapping point to point (P2P) WDM. One of the advantages of this solution is the capability of reserving a $\lambda$-channel for each ONU unit. In the basic configuration, 8 PtP WDM channels guarantee a coexistence with older PONs. The unused wavelength range can then be assigned to other PtP WDM channels. For the PtP WDM, a wavelength range of 1603 to $1625 \mathrm{~nm}$ or an extended range of 1524 to $1625 \mathrm{~nm}$ is reserved for both the upstream direction and the downstream direction. The basic range (also known as shared) is used to achieve full coexistence with older PON standards. The expanded spectrum enables unused bands to be assigned to PtP WDM. The expanded band is also used for the implementation of new PON infrastructure ("greenfield scenario"), in which the coexistence condition is not necessary [66]. PtP WDM communication is a point-to-point communication; therefore the NG-PON2 is historically the first PON standard supporting multiwavelength channels [67]. PtP WDM channels support the following transfer rates: $1.25 \mathrm{~Gb} / \mathrm{s}, 2.5 \mathrm{~Gb} / \mathrm{s}$ and $10 \mathrm{~Gb} / \mathrm{s}$ [68-70].

In the case of both technologies (TWDM and PtP WDM), PLOAM controls messages to support multiple wavelengths, and security key management, end-to-end unit management, wavelength channel management and protection are used, which is an extension of the PLOAM functionality from the previous XG-PON standard. For communication with the OLT, the end units require one channel at a certain wavelength for each direction [67].

Each channel (TWDM or PtP WDM) is assigned to one OLT channel termination (OLT CT) [71]. CT terminates the channel on the OLT side. The WDM multiplexer ensures that these parts are connected to the optical line. ONUs can be moved between individual TWDM channels, which enables it to respond to different network situations. It is also possible to evenly distribute the load between the individual channels or, in the case of a failure of the $\mathrm{CT}$ member, to move the associated end units to a functional CT member. Correct operation with multiple wavelengths and their changes are the responsibility of the inter-channel termination protocol (ICTP) protocol. This protocol is also responsible for transferring ONUs to different wavelengths (handover), performance monitoring, TWDM security or mitigation of consequences caused by the modified ONU [67,68]. An example of communication within the NG-PON2 standard is shown in Figure 7. ONU units are colorless or contain tunable filters. 


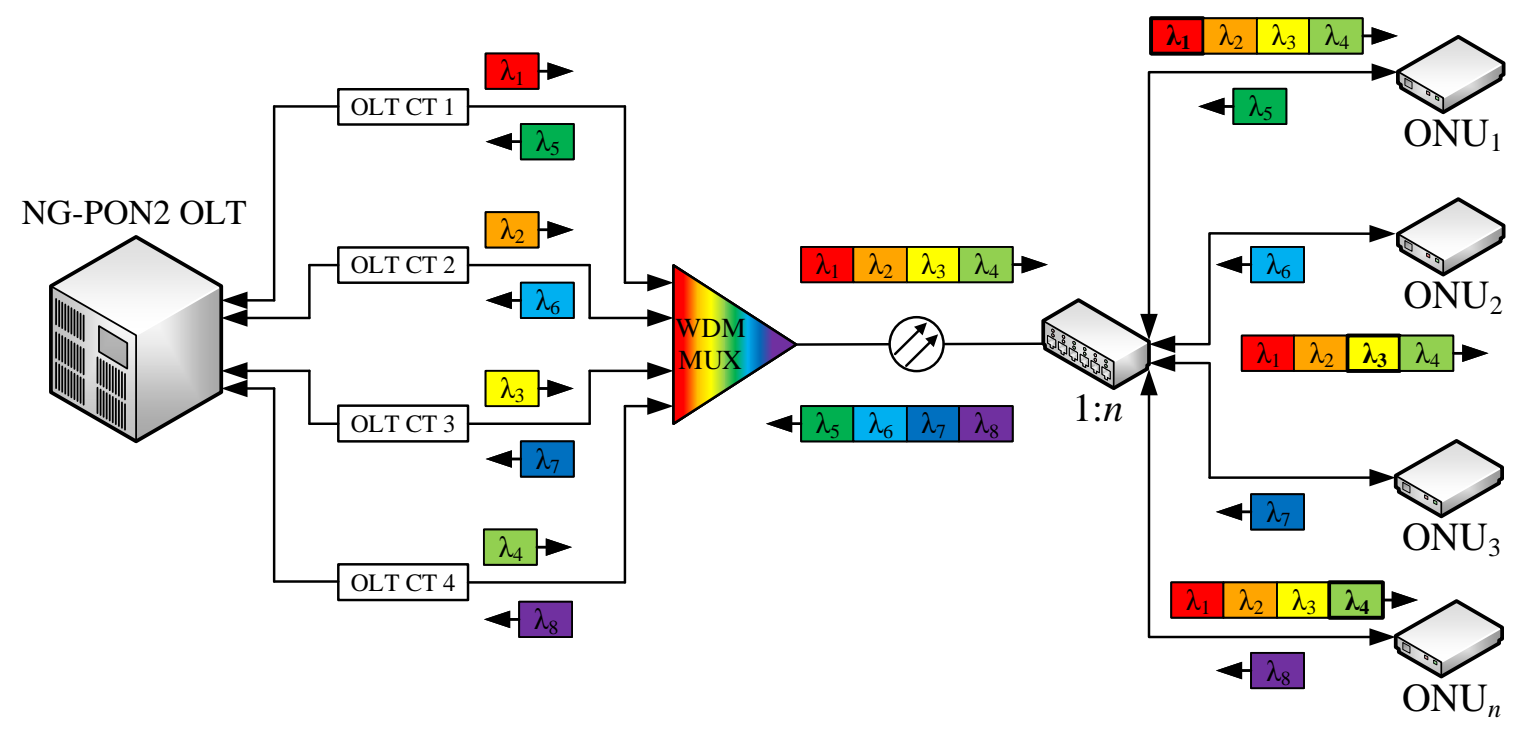

Figure 7. Principle of communication in the next-generation PON stage 2 (NG-PON2) network [68].

NG-PON2 also supports the X-GEM encapsulation method, based on the GEM method used in the GPON standard. The X-GEM frame has the same structure as the XG-PON frame shown in Figure 6. The X-GEM frame can be reused to encapsulate the data units of different network technologies [68].

\subsubsection{Deploying the NG-PON2 System}

Deployment of the system is dependent on affordability of the tunable receivers, which is an essential part of the ONU endpoints. Authors of [72] created and successfully tested the TWDM-based PON prototype. This prototype has a total number of 4 channels in the downstream direction $(10 \mathrm{~Gb} / \mathrm{s}$ per channel) and uses the same number of channels in the upstream direction $(2.5 \mathrm{~Gb} / \mathrm{s}$ per channel). The associated OLT uses the SOA preamplifier. Each ONU has a tunable filter that is used to select the appropriate wavelength. To set the wavelength, the proprietary PLOAM messages that inform of the changes of wavelengths were used. An overview of TWDM implementation is depicted in Table 1.

Table 1. Overview made implementations of TWDM [44].

\begin{tabular}{cccc}
\hline Bandwidth [Gb/s] & Split Ratio & Distance $[\mathbf{k m}]$ & Attenuation [dB] \\
\hline $40 / 40$ & $1: 256$ & 25 & 31 \\
$40 / 40$ & $1: 1000$ & 40 & 39 \\
$40 / 40$ & $1: 1024$ & 50 & 43 \\
$40 / 40$ & $1: 256$ & 75 & - \\
$40 / 40$ & $1: 46$ & 100 & - \\
$100 / 100$ & $1: 1024$ & 25 & 42 \\
$40 / 10$ & $1: 64$ & 20 & 36 \\
\hline
\end{tabular}

The American company Verizon planned to deploy the NG-PON2 standard in 2018. The laboratory tests of the system have been completed, and the deployment is to be completed by the beginning of 2018. This solution is developed by Calix and is referred to as the AXOS E9-2 Intelligent Edge System. This system enables the deployment of a single access network for various types of services, including mobile services. This deployment should be the first deployment of the NG-PON2 standard in real operation. Implementation was planned in Tampa, Florida [73].

\subsubsection{Future Development}

NG-PON2 is developed to deliver the high transmission capacity for an extensive range of applications and services. The deployment of the system in mobile networks is being considered. 
In this case, PtP WDM and its wavelength bands are reserved for mobile networks. For the remaining network services, TWDM wavelength ranges are reserved. An example of the network infrastructure is provided in Figure 8.

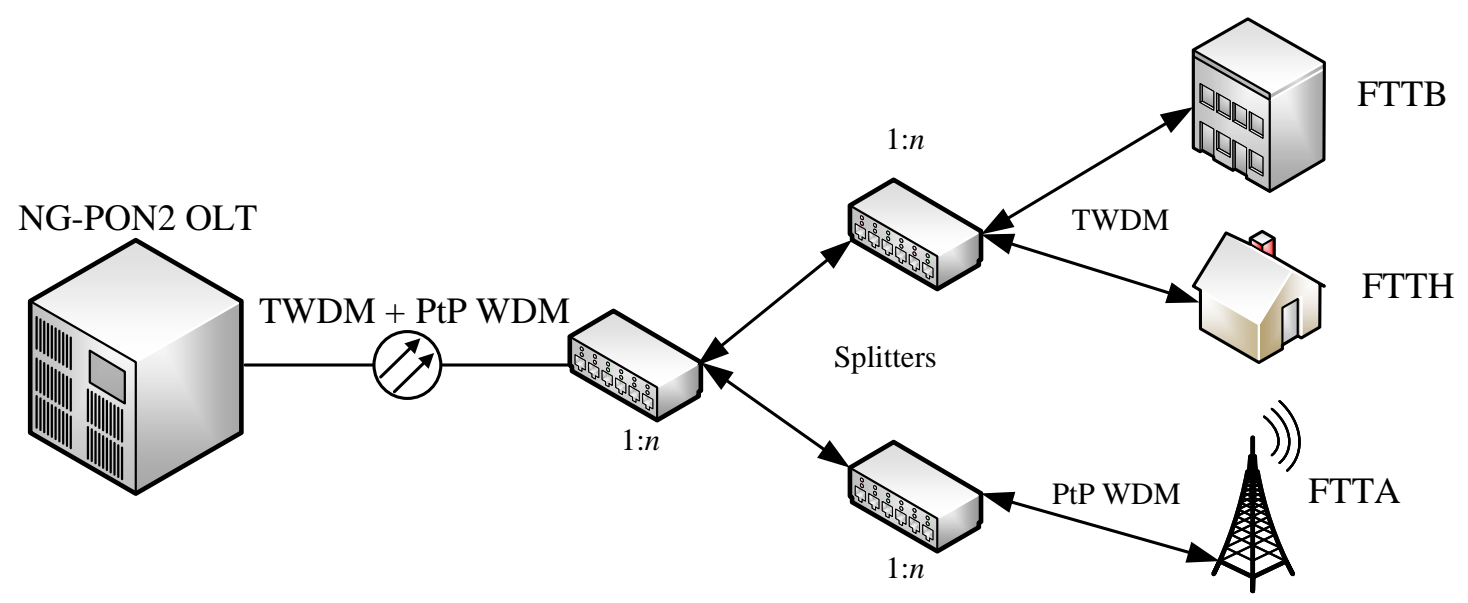

Figure 8. TWDM and point to point wavelength division multiplex (PtP WDM) usage [44].

A recent update of the G.989.2 recommendation includes support for the $80 \mathrm{~Gb} / \mathrm{s}$ transfer rate. Increasing the transfer rate from $10 \mathrm{~Gb} / \mathrm{s}$ to $25 \mathrm{~Gb} / \mathrm{s}$ per $\lambda$-channel is also being considered [74].

Research that focuses on mobile optical networks based on passive optical infrastructure is underway. With further development of NG-PON2, an increase in the coverage of the territory by mobile networks and a reduction in the costs of building the necessary infrastructure (a common multipurpose network infrastructure that combines several telecommunication services) are expected. The bandwidth offered by the NG-PON2 is ideal for cloud services and facilitates the use of big data applications [44].

In Japan, approximately $30 \%$ of the total data flow is caused by conventional cable networks, and approximately $50 \%$ of the total data flow is attributed to radio networks [75]. According to Cisco, network traffic generated by smart phones will exceed computer network traffic by 2020. Mobile service providers use macrocells that are capable of serving thousands of end-users and smaller cells that are capable of serving tens to hundreds of end-users (depending on areas and demand for mobile services). Continuous densification of mobile infrastructure forces mobile service providers to deploy corresponding network infrastructures that link these cells to satisfy the high bandwidth requirements that are likely to continuously increase in the future [76].

The deployment of the fifth generation (5G) of mobile networks is also expected, and their standardization could be completed by 2020. Some 5G mobile network functionalities could provide users with the maximum capacity of $10 \mathrm{~Gb} / \mathrm{s}$. The optical transmission media will have high importance for the proper functioning of these networks. The 5G networks should be packet-oriented; therefore, individual transmissions can be transmitted over conventional PONs, which are based on TDM/TDMA technologies, and TWDM and PtP WDM (NG-PON2) technologies. The development of the fifth generation of mobile networks can influence the future development of PONs [74].

Currently, telecommunication service providers aim to reduce the costs of building new networks and the operation of existing networks. The convergence of telecommunication networks has helped to unify various telecommunication services to operate over a common network infrastructure. However, there are still new technologies such as network virtualization or SDN [74]. In addition to the traditional triple play services (video, voice and data) that were initially introduced with FTTH networks, the share of data flows for these new services continues to increase, e.g., data centers for the previously mentioned mobile networks, Internet of Things (IoT) and cloud applications. [75].

The final comparison of all presented standards of passive optical networks is depicted in Table 2. 
Table 2. Comparison of presented passive optical networks standards/recommendations $[10,29,32,41$, $42,49,58,59,62,65]$.

\begin{tabular}{|c|c|c|c|c|c|}
\hline $\begin{array}{l}\text { Standard/ } \\
\text { Recommendation }\end{array}$ & APON & BPON & GPON & XG-PON & NG-PON2 \\
\hline Approved & 1998 & 2001 & 2003 & 2010 & 2013 \\
\hline Line code & NRZ (OOK) & NRZ (OOK) & NRZ (OOK) & NRZ (OOK) & NRZ (OOK) \\
\hline Traffic mode & ATM & ATM & GEM & X-GEM & X-GEM \\
\hline $\begin{array}{l}\text { Wavelength range } \\
\text { for downstream }\end{array}$ & $1480-1580 \mathrm{~nm}$ & $1480-1580 \mathrm{~nm}$ & $1480-1500 \mathrm{~nm}$ & $1575-1580 \mathrm{~nm}$ & $1596-1603 \mathrm{~nm}$ \\
\hline $\begin{array}{l}\text { Wavelength range } \\
\text { for upstream }\end{array}$ & $1260-1360 \mathrm{~nm}$ & $1260-1360 \mathrm{~nm}$ & $1260-1360 \mathrm{~nm}$ & $1260-1280 \mathrm{~nm}$ & $\begin{array}{c}1524-1544 \mathrm{~nm} \\
\text { (wide band option) } \\
1528-1540 \mathrm{~nm} \\
\text { (reduced band option) } \\
1532-1540 \mathrm{~nm} \\
\text { (narrow band option) }\end{array}$ \\
\hline $\begin{array}{l}\text { Transmission } \\
\text { speed downstream }\end{array}$ & $622 \mathrm{Mb} / \mathrm{s}$ & up to $1244.16 \mathrm{Mb} / \mathrm{s}$ & up to $2488.32 \mathrm{Mb} / \mathrm{s}$ & up to $9953.28 \mathrm{Mb} / \mathrm{s}$ & up to $9953.28 \mathrm{Mb} / \mathrm{s}$ \\
\hline $\begin{array}{l}\text { Transmission } \\
\text { speed upstream }\end{array}$ & $155 \mathrm{Mb} / \mathrm{s}$ & up to $622 \mathrm{Mb} / \mathrm{s}$ & up to $1244.16 \mathrm{Mb} / \mathrm{s}$ & up to $2488.32 \mathrm{Mb} / \mathrm{s}$ & up to $9953.28 \mathrm{Mb} / \mathrm{s}$ \\
\hline Split ratio & up to $1: 32$ & up to $1: 32$ & up to $1: 64$ & up to $1: 256$ & over 1:256 \\
\hline
\end{tabular}

One of the technologies considered for new next generation passive optical networks is higher order modulation formats. Today long-haul networks, using complex modulation formats, can transmit more than 100 Gbps [77-79] in a single optical channel. Mostly quadrature amplitude modulation (QAM) or phase-shift keying (PSK) modulation formats in combination with polarization multiplex are used [80-84]. For next generation PON modulation, formats such as pulse-amplitude modulation (PAM)-4 [85,86] and QAM seem to be the most appropriate. However, it is still only a matter of research, as the costs for this technology are high $[87,88]$. We can also mention code division multiplexing (CDM) method for PON. CDM is a method of code multiplexing, which is known primarily from $3 \mathrm{G}$ mobile technologies wideband code division multiple access (WCDMA). All users use the whole allocated spectrum at the same time. Their data are distinguished from each other by the assigned binary code. Multiplying this code with the original data produces a broadband signal and occurs to spread information across the spectrum [89-91]. OFDM uses hundreds to thousands of subcarrier frequencies. This is a broadband modulation where fast serial stream is transformed into a slower parallel stream, which is transmitted using subcarriers components. As a result, the adjacent components are orthogonal to each other and do not occur interference in mutual overlapping. So far, this method has found application in particular in the field of wireless fidelity (WiFi), worldwide interoperability for microwave access (WiMAX), long term evolution (LTE) and digital video broadcasting - terrestrial (DVB-T) [92]. The researchers also consider OFDM as a suitable modulation format for passive optical network modulation format [93-96]. As a last technology for future PON, coherent optical transmission system can be considered. Coherent optical systems are currently used mainly for a single channel transmission above $100 \mathrm{G}$. The principle itself has been known since the 1960s as a technology mainly used in microwave area/field. In a receiver, a local oscillator (LO) used for increasing the power level of a received signal. In the field of optical networks, coherent systems were muffled by a massive development of EDFA amplifiers. Nowadays, however, high-speed systems are getting off to a big start to solve the problems of dispersions to which a coherent system is immune. Coherent systems are also able to accept chromatic dispersion from 30,000 to $80,000 \mathrm{ps} / \mathrm{nm}$, which would mean a theoretical reaching of system over $3000 \mathrm{~km}$ without chromatic dispersion compensation [97-101]. Furthermore, it is theoretically resistant to polarization mode 
dispersion up to $30 \mathrm{ps}$. On the other hand, a coherent system is only the beginning, the main part of these systems is electrical and in particular digital signal processing (DSP) signal processing [102-110].

\section{Conclusions}

PONs are definitively here, and new developments ensure that they will remain for years to come. New standards for high-speed PONs exist, and additional standards are being prepared. We discussed different technologies that range from cost-effective solutions for everyone to current examples that can satisfy even business needs. We described the data communication among PON elements: OLTs and ONUs and schematics of all data messages.

All mentioned PON technologies are similar in some aspects because they share the same fiber network and physical topologies. On the other hand, there are quite large differences in ITU- and IEEE-based approaches, which are already known from ATM and Ethernet switching networking technologies. Although standards are important, the lack of standards should not hinder the creation of new approaches, for example, deployment of optical amplifiers in PONs, including mature technologies such as EDFAs and SOAs.

New trends of open networking promoted by megadata and hyperdata center companies should be considered for new trends in PON deployment to avoid any vendor dependencies and lock-ins. Open networking can ensure that technologies are replaced or migrated to new equipment as needed. These new open trends are not standardized but cannot be disregarded because they are emerging in many parts of the world, especially in North America and Asia. The support of new applications, such as accurate time transfer or distributed fiber sensing, should be considered. This new class of applications may not appear to be appropriate for a PON environment, and current user requirements and new open approaches may prevent well-known failed predictions, such as the famous quotes "I think there is a world market for maybe five computers" or "There is no reason anyone would want a computer in their home". With open ideas for networking deployment, we may reserve these famous quotes related to PONs for future users.

The article does not cover nonlinear phenomena in passive optical networks. From ODN point of view and based on parameters of current PONs we do not think that nonlinear phenomena can affect signal significantly. If we consider on-off keying (OOK) modulation with 100ps pulse duration and average power of about $5 \mathrm{dBm}$, the peak power is less than $7 \mathrm{~mW}$. Moreover, the maximum recommended distance for PON is $20 \mathrm{~km}$, which is a relatively short distance. The laser phase is another critical parameter that should not be neglected in a high-speed transmission system, especially in case of high order modulation formats, which is not the case. We do not think that phase noise in simple OOK modulation can influence the performance of the system and its performance.

Funding: This research has been supported by the projects of the Ministry of Interior under grant no. VI20172020110 registrations (Reduction of security threats at optical networks), E-infrastructure CESNET-modernization, registration numberCZ.02.1.01/0.0/0.0/16_013/0001797, and National Natural Science Foundation of China (NSFC 61671092).

Acknowledgments: Tomas would like to give thanks to Ales Buksa for his support at the University in memorial. Ales has taught and inspired him with many things in his personal life.

Conflicts of Interest: The authors declare no conflict of interest.

\section{Abbreviations}

The following abbreviations are used in this manuscript:

ACTS Advanced communication technologies and services

ADSL Asymmetric digital subscriber line

APON Asynchronous transfer mode passive optical network

ATM Asynchronous transfer mode

AWG Arrayed waveguide gratings

B-ISDN Broadband integrated services digital network 


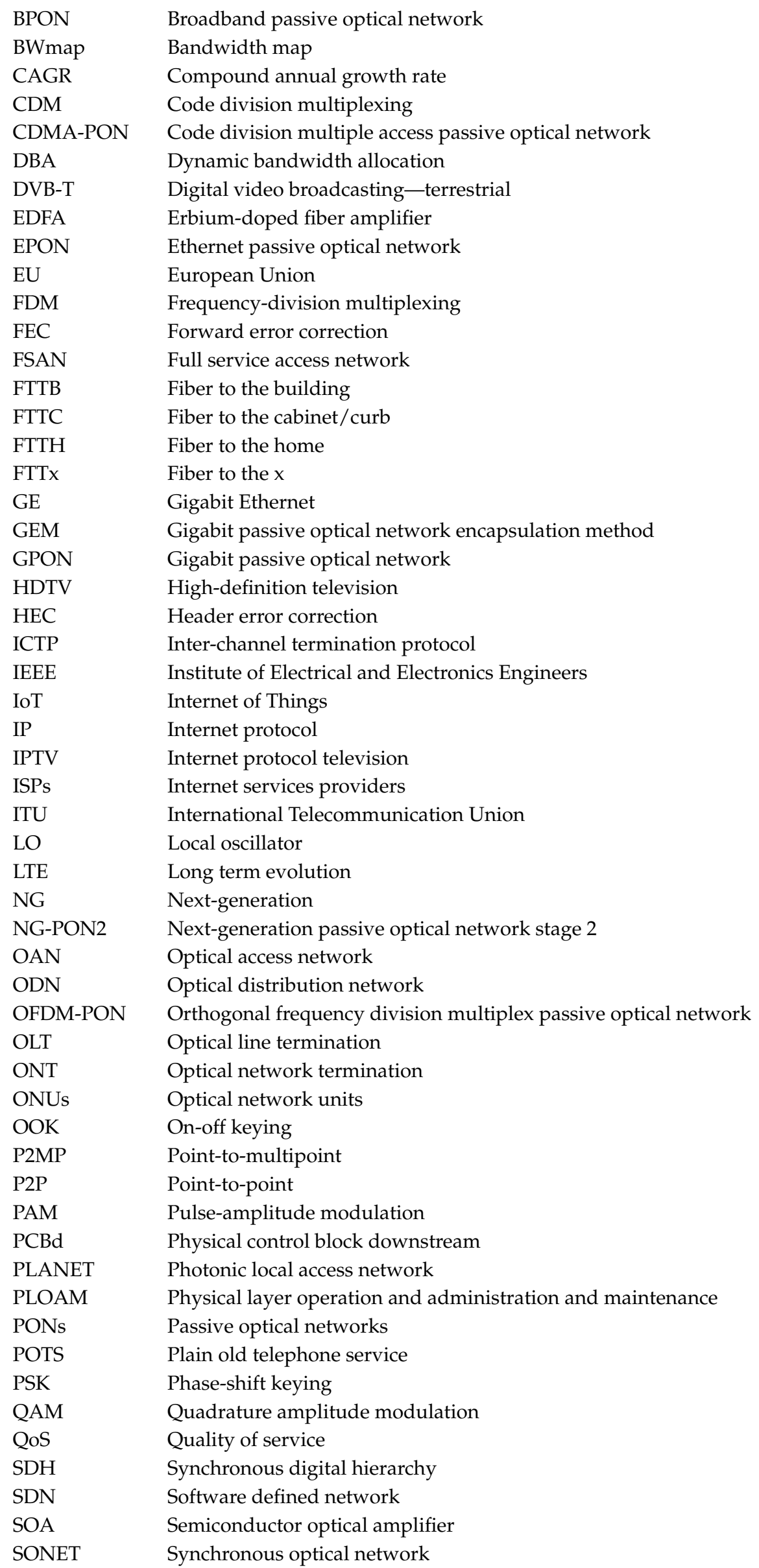




$\begin{array}{ll}\text { T-CONT } & \text { Transmission container } \\ \text { T-PON } & \text { Telephony over passive optical network } \\ \text { TDM } & \text { Time division multiplexing } \\ \text { TDMA } & \text { Time division multiple access } \\ \text { TWDM } & \text { Time and wavelength division multiplexing } \\ \text { USA } & \text { United States of America } \\ \text { VNI } & \text { Visual networking index } \\ \text { VDSL } & \text { Very-high-speed digital subscriber line } \\ \text { VoD } & \text { Video on demand } \\ \text { VoIP } & \text { Voice over Internet protocol } \\ \text { WCDMA } & \text { Wideband code division multiple access } \\ \text { WDM } & \text { Wavelength division multiplex } \\ \text { WiFi } & \text { Wireless fidelity } \\ \text { WiMAX } & \text { Worldwide interoperability for microwave access } \\ \text { WWW } & \text { World wide web } \\ \text { XG-PON } & \text { Next-generation passive optical network } \\ \text { XGS-PON } & \text { Next-generation symmetrical passive optical network } \\ \text { XGTC } & \text { Next-generation passive optical network transmission convergence }\end{array}$

\section{References}

1. Ford, G.S. Is Faster Better? Quantifying the Relationship Between Broadband Speed and Economic Growth. Telecommun. Policy 2018, 42, 766-777. [CrossRef]

2. Steenbruggen, J.; Tranos, E.; Nijkamp, P. Data from Mobile Phone Operators: A Tool for Smarter Cities? Telecommun. Policy 2015, 39, 335-346. [CrossRef]

3. Falch, M.; Henten, A. Dimensions of Broadband Policies and Developments. Telecommun. Policy 2018, 42, 715-725. [CrossRef]

4. Hernandez, J.A.; Sanchez, R.; Martin, I.; Larrabeiti, D. Meeting The Traffic Requirements Of Residential Users In The Next Decade With Current Ftth Standards: How Much? How Long? IEEE Commun. Mag. 2019, 57, 120-125. [CrossRef]

5. Vu Thang, N.; Dac Tung, V.; Duc Hoan, N. Architecture Of Integer Motion Estimation Hevc For Encoding 8K Video. In Proceedings of the 2017 International Conference on Advanced Technologies for Communications (ATC), Quy Nhon, Vietnam, 18-20 October 2017; pp. 279-284.

6. Kim, Y.-H.; Huh, J.; Jeong, J. Distributed Video Transcoding System For $8 \mathrm{~K} 360^{\circ}$ Vr Tiled Streaming Service. In Proceedings of the 2018 International Conference on Information and Communication Technology Convergence (ICTC), Jeju, Korea, 17-19 October 2018; pp. 592-595.

7. Cisco Annual Internet Report (2018-2023) White Paper. Available online: https:/ / bit.ly/2X4s89S (accessed on 27 May 2020).

8. Girard, A. Fttx Pon Technology and Testing; EXFO: Richardson, TX, USA, 2005.

9. Forzati, M.; Mattsson, C. Socio-Economic Return of FTTH Investment in Sweden, a Prestudy. Available online: https: / / bit.ly /2XAp9oL (accessed on 27 May 2020).

10. G.983.1: Broadband Optical Access Systems Based on Passive Optical Networks (PON). Available online: https:/ / bit.ly/2AZscPE (accessed on 27 May 2020).

11. Stern, J.R.; Ballance, J.W.; Faulkner, D.W.; Hornung, S.; Payne, D.B.; Oakley, K. Passive Optical Local Networks For Telephony Applications And Beyond. Electron. Lett. 1987, 23, 1255-1257. [CrossRef]

12. Next Generation Access Networks (NGA): EUR Lex: Access to European Union Law. Available online: https:/ / bit.ly/36zL03U (accessed on 28 May 2020).

13. Google Fiber: Google Fiber I High Speed Internet Service \& TV. Available online: https:/ fiber.google.com/ (accessed on 28 May 2020).

14. AT\&T: AT\&T Fiber-Make High Speed Internet Even Faster. Available online: https://www.att.com/ internet/fiber/ (accessed on 28 May 2020). 
15. Zhou, L.W.; Mas Machuca, C.; Zhao, R.; Grunert, K. Migration towards Fibre to the Home: Key Cost Factors. In Proceedings of the Asia Communications and Photonics Conference and Exhibition, Shanghai, China, 8-12 December 2010; pp. 399-400.

16. Forzati, M.; Bianchi, A.; Chen, J.; Grobe, K.; Lannoo, B.; Machuca, C.M.; Point, J.-C.; Skubic, B.; Verbrugge, S.; Weis, E.; et al. Next-Generation Optical Access Seamless Evolution: Concluding Results Of The European Fp7 Project Oase. J. Opt. Commun. Netw. 2015, 7, 109-123. [CrossRef]

17. Kim, K. On The Evolution of Pon-Based Ftth Solutions. Inf. Sci. 2003, 149, 21-30. [CrossRef]

18. Van de Voorde, I.; Van der Plas, C. Full Service Optical Access Networks: Atm Transport On Passive Optical Networks. IEEE Commun. Mag. 1997, 35, 70-75. [CrossRef]

19. Chanclou, P.; Gosselin, S.; Palacios, J.F.; Alvarez, V.L.; Zouganeli, E. Overview Of The Optical Broadband Access Evolution: A Joint Article By Operators In The Ist Network Of Excellence E-Photon/One. IEEE Commun. Mag. 2006, 44, 29-35. [CrossRef]

20. Vetter, P.; Goderis, D.; Verpooten, L.; Granger, A. Systems Aspects Of Apon/Vdsl Deployment. IEEE Commun. Mag. 2000, 38, 66-72. [CrossRef]

21. Ringoot, E.; Janssens, N.; Tassent, A.; Angeloupoulos, J.; Blondia, C.; Vetter, P. Demonstration Of Dynamic Medium Access Control For Apon And Superpon. In Proceedings of the GLOBECOM'01, IEEE Global Telecommunications Conference (Cat. No.01CH37270), San Antonio, TX, USA, 25-29 November 2001; pp. 1570-1574.

22. James, K.A.; Fisher, S. Developments In Optical Access Networks. BT Technol. J. 2002, 20, 81-90. [CrossRef]

23. Gagnaire, M.; Stojanovski, S. Stream Traffic Management Over An Atm Passive Optical Network. Comput. Netw. 2000, 32, 571-586. [CrossRef]

24. Oakley, K.; Jensen, J.D.; Walkoe, W. British Telecom Tpon Application In The Us Network. In Proceedings of the IEEE Global Telecommunications Conference, 1989, and Exhibition. 'Communications Technology for the 1990s and Beyond, Dallas, TX, USA, 27-30 November 1989; pp. 1340-1345.

25. Bickers, L.; Cade, I.; James, K.; James, S. Operations And Maintenance Experimental Testbed For A Business Tpon System. In Proceedings of the IEEE Global Telecommunications Conference GLOBECOM '91: Countdown to the New Millennium. Conference Record, Phoenix, AZ, USA, 2-5 December 1991; pp. 569-571.

26. Hossen, M.; Hanawa, M. Adaptive Limited Dba Algorithm For Multi-Olt Pon-Based Ftth And Wireless Sensor Networks. In Proceedings of the 2012 18th Asia-Pacific Conference on Communications (APCC), Jeju Island, Korea, 15-17 October 2012; pp. 372-377.

27. Subramaniam, S. Emerging Optical Network Technologies: Architectures, Protocols and Performance; Sivalingam, K.M., Ed.; Springer: New York, NY, USA, 2005.

28. Jang, J.; Park, E.K. Dynamic Resource Allocation for Quality of Service on A Pon with Home Networks. IEEE Commun. Mag. 2000, 38, 184-190. [CrossRef]

29. G.984.3: Gigabit-Capable Passive Optical Networks (G-PON): Transmission Convergence Layer Specification. Available online: https: / / www.itu.int/rec/T-REC-G.984.3 (accessed on 28 May 2020).

30. Van der Plas, G.; Smets, R.; Suard, B.; Verbiest, W. Demonstration of an Atm-Based Passive Optical Network in the Ftth Trial On Bermuda. In Proceedings of the GLOBECOM '95, Singapore, 14-16 November 1995; pp. 988-992.

31. Phillips, A.J. Reliability of Superpon Systems. In Proceedings of the Sixth IEE Conference on Telecommunications, Edinburgh, UK, 29 March-1 April 1998; pp. 219-223.

32. G.983.3: A Broadband Optical Access System with Increased Service Capability by Wavelength Allocation. Available online: https: / / www.itu.int/rec/T-REC-G.983.3 (accessed on 28 May 2020).

33. Filka, M. Optoelectronics for Telecommunications and Informatics; Optokon \& Methode Electronic: Dallas, TX, USA, 2009.

34. Mukherjee, B. Optical Wdm Networks; Optical Networks, from Physical Layer to Service Offerings; Springer: New York, NY, USA, 2006.

35. Antoniades, N.N.; Ellinas, G.; Roudas, I. Wdm Systems and Networks: Modeling, Simulation, Design and Engineering; Springer: New York, NY, USA, 2012.

36. Hood, D. Gigabit-Capable Passive Optical Networks; Wiley: Hoboken, NJ, USA, 2012.

37. Lin, W.-P. Reducing Multiple Optical Carriers Interference in Broad-Band Passive Optical Networks. IEEE Photonics Technol. Lett. 1997, 9, 368-370. [CrossRef] 
38. Shumate, P.W. Fiber-To-The-Home: 1977-2007. J. Lightw. Technol. 2008, 26, 1093-1103. [CrossRef]

39. Abrams, M.; Becker, P.C.; Fujimoto, Y.; O’Byrne, V.; Piehler, D. Fttp Deployments in the United States And Japan-Equipment Choices And Service Provider Imperatives. J. Lightw. Technol. 2005, 23, 236-246. [CrossRef]

40. Gianordoli, S.; Rasztovits-Wiech, M.; Stadler, A.; Grabenhorst, R. Next Generation Pon. Elektrotechnik und Informationstechnik 2006, 123, 78-82. [CrossRef]

41. G.984.1: Gigabit-Capable Passive Optical Networks (GPON): General Characteristics. Available online: https:/ / www.itu.int/rec/T-REC-G.984.1-200803-I/en (accessed on 28 May 2020).

42. G.984.2: Gigabit-Capable Passive Optical Networks (G-PON): Physical Media Dependent (PMD) Layer Specification. Available online: https://www.itu.int/rec/T-REC-G.984.2-201908-I/en (accessed on 28 May 2020).

43. Cale, I.; Salihovic, A.; Ivekovic, M. Gigabit Passive Optical Network-Gpon. In Proceedings of the 2007 29th International Conference on Information Technology Interfaces, Cavtat, Croatia, 25-28 June 2007; pp. 679-684.

44. Abbas, H.S.; Gregory, M.A. The Next Generation of Passive Optical Networks: A Review. J. Netw. Comput. Appl. 2016, 67, 53-74. [CrossRef]

45. Skubic, B.; Chen, J.; Ahmed, J.; Wosinska, L.; Mukherjee, B. A Comparison of Dynamic Bandwidth Allocation for Epon, Gpon, and Next-Generation Tdm Pon. IEEE Commun. Mag. 2009, 47, S40-S48. [CrossRef]

46. Jiang, J.; Handley, M.R.; Senior, J.M. Dynamic Bandwidth Assignment Mac Protocol for Differentiated Services over Gpon. Electron. Lett. 2006, 42, 653-655. [CrossRef]

47. Qiu, X.-Z.; Ossieur, P.; Bauwelinck, J.; Yi, Y.; Verhulst, D.; Vandewege, J.; DeVos, B.; Solina, P. Development of Gpon Upstream Physical-Media-Dependent Prototypes. J. Lightw. Technol. 2004, 22, 2498-2508. [CrossRef]

48. Weis, E.; Hölzl, R.; Breuer, D.; Lange, C. Gpon Ftth Trial-Lessons Learned. In Proceedings of the 2009 Asia Communications and Photonics conference and Exhibition (ACP), Shanghai, China, 2-6 November 2009; p. 76330J-1-7.

49. G.987.1: 10-Gigabit-Capable Passive Optical Networks (XG-PON): General Requirements. Available online: https:/ / www.itu.int/rec/T-REC-G.987.1-201603-I/en (accessed on 28 May 2020).

50. Wong, E. Next-Generation Broadband Access Networks and Technologies. J. Lightw. Technol. 2012, 30, 597-608. [CrossRef]

51. Effenberger, F.J. Industrial Trends and Roadmap of Access. J. Lightw. Technol. 2017, 35, 1142-1146. [CrossRef]

52. Chen, L.; Dahlfort, S.; Hood, D. Evolution of Pon: 10G-Pon and Wdm-Pon. In Proceedings of the Asia Communications and Photonics Conference and Exhibition, Shanghai, China, 8-12 December 2010; pp. 709-711.

53. Hajduczenia, M.; da Silva, H.J.A. Next Generation Pon Systems-Current Status. In Proceedings of the 2009 11th International Conference on Transparent Optical Networks, Azores, Portugal, 28 June-2 July 2009; pp. 1-8.

54. Jain, S.; Effenberger, F.; Szabo, A.; Feng, Z.; Forcucci, A.; Guo, W.; Luo, Y.; Mapes, R.; Zhang, Y.; O’Byrne, V. World's First Xg-Pon Field Trial. J. Lightw. Technol. 2011, 29, 524-528. [CrossRef]

55. G.984.5: Gigabit-Capable Passive Optical Networks (G-PON): Enhancement Band. Available online: https: / / www.itu.int/rec/T-REC-G.984.5-201405-I/en (accessed on 28 May 2020).

56. Effenberger, F.J. The Xg-Pon System: Cost Effective 10 Gb/S Access. J. Lightw. Technol. 2011, $29,403-409$. [CrossRef]

57. Muciaccia, T.; Gargano, F.; Passaro, V. Passive Optical Access Networks: State of the Art and Future Evolution. Photonics 2014, 1, 323-346. [CrossRef]

58. G.9807.1: 10-Gigabit-Capable Symmetric Passive Optical Network (XGS-PON). Available online: https: / / www.itu.int/rec/T-REC-G.9807.1/en (accessed on 2 June 2020).

59. G.987.3: 10-Gigabit-Capable Passive Optical Networks (XG-PON): Transmission Convergence (TC) Layer Specification. Available online: https:/ / www.itu.int/rec/T-REC-G.987.3/en (accessed on 2 June 2020).

60. Li, C.; Guo, W.; Wang, W.; Hu, W.; Xia, M. Bandwidth Resource Sharing On The Xg-Pon Transmission Convergence Layer In A Multi-Operator Scenario. J. Opt. Commun. Netw. 2016, 8, 835-843. [CrossRef]

61. Yiannopoulos, K.; Varvarigos, E.A.; Papadimitriou, G.; Gravalos, I. Burst-By-Burst Dynamic Bandwidth Allocation For Xg-Pons. IET Netw. 2016, 5, 47-55. [CrossRef]

62. G.989.1: 40-Gigabit-Capable Passive Optical Networks (NG-PON2): General Requirements. Available online: https:/ / www.itu.int/rec/T-REC-G.989.1/e (accessed on 2 June 2020). 
63. Chen, X.; Zhang, Z.; Hu, X. The Evolution Trends of Pon and Key Techniques for Ng-Pon. In Proceedings of the 9th International Conference on Information, Communications \& Signal Processing, Tainan, Taiwan, 10-13 December 2013; pp. 1-6. [CrossRef]

64. Digital Czech Republic v. 2.0-The Way to the Digital Economy. Available online: https://bit.ly/2DGiEYn (accessed on 2 June 2020).

65. G.989.2: 40-Gigabit-Capable Passive Optical Networks 2 (NG-PON2): Physical Media Dependent (PMD) Layer Specification. Available online: https:/ / www.itu.int/rec/T-REC-G.989.2-201902-I/en (accessed on 2 June 2020).

66. Nesset, D. Ng-Pon2 Technology and Standards. J. Lightw. Technol. 2015, 33, 1136-1143. [CrossRef]

67. Khotimsky, D.A. Ng-Pon2 Transmission Convergence Layer: A Tutorial. J. Lightw. Technol. 2016, 34, 1424-1432. [CrossRef]

68. G.989.3: 40-Gigabit-Capable Passive Optical Networks (NG-PON2): Transmission Convergence Layer Specification. Available online: https:/ / www.itu.int/rec/T-REC-G.989.3/en (accessed on 2 June 2020).

69. Wey, J.S.; Nesset, D.; Valvo, M.; Grobe, K.; Roberts, H.; Luo, Y.; Smith, J. Physical Layer Aspects of Ng-Pon2 Standards-Part 1: Optical Link Design [Invited]. J. Opt. Commun. Netw. 2016, 8, 33-42. [CrossRef]

70. Luo, Y.; Roberts, H.; Grobe, K.; Valvo, M.; Nesset, D.; Asaka, K.; Rohde, H.; Smith, J.; Wey, J.S.; Effenberger, F. Physical Layer Aspects Of Ng-Pon2 Standards-Part 2: System Design And Technology Feasibility [Invited]. J. Opt. Commun. Netw. 2016, 8, 43-52. [CrossRef]

71. Luo, Y.; Zhou, X.; Effenberger, F.; Yan, X.; Peng, G.; Qian, Y.; Ma, Y. Time- and Wavelength-Division Multiplexed Passive Optical Network (Twdm-Pon) For Next-Generation Pon Stage 2 (Ng-Pon2). J. Lightw. Technol. 2013, 31, 587-593. [CrossRef]

72. Lau, M.F.; Vetter, P.; Deppisch, B.; Farah, B.; Phlmann, W.; Duque, A.; Galaro, J.; van Veen, D.; Pfeiffer, T. System Demonstration of a Time and Wavelength-Set Division Multiplexing Pon. In Proceedings of the 39th European Conference and Exhibition on Optical Communication (ECOC 2013), Institution of Engineering and Technology, London, UK, 22-26 September 2013; pp. 564-566.

73. Verizon, Calix Deploy Commercial NG-PON2. Available online: https://bit.ly/2MRO2sW (accessed on 2 June 2020).

74. Nesset, D. Pon Roadmap [Invited]. J. Opt. Commun. Netw. 2017, 9, A71-A76. [CrossRef]

75. Sugie, T.; Nakamura, H. Recent Advances In Access Networks And Their Components Technologies. In Proceedings of the 2015 International Conference on Microwave and Photonics (ICMAP), Dhanbad, India, 11-13 December 2015; pp. 1-2.

76. Bourg, K.; Ten, S.; Whitman, R.; Jensen, J.; Diaz, V. The Evolution of Outside Plant Architectures Driven By Network Convergence And New Pon Technologies. In Proceedings of the 2017 Optical Fiber Communications Conference and Exhibition (OFC), Los Angeles, CA, USA, 19-23 March 2017; pp. 1-3.

77. Lach, E.; Idler, W. Modulation formats for 100G and beyond. Opt. Fiber Technol. 2011, 17, 377-386. [CrossRef]

78. Dong-Nhat, N.; Elsherif, M.A.; Malekmohammadi, A. Investigations of high-speed optical transmission systems employing Absolute Added Correlative Coding (AACC). Opt. Fiber Technol. 2016, 30, $23-31$. [CrossRef]

79. Houtsma, V.; van Veen, D.; Chow, H. Demonstration of Symmetrical 25 Gb/s TDM-PON With Multilevel Interleaving of Users. J. Lightw. Technol. 2016, 34, 2005-2010. [CrossRef]

80. Jung, S.P.; Cho, K.Y.; Takushima, Y.; Chung, Y.C. Recent progresses in coherent WDM PON technologies. In Proceedings of the 2010 12th International Conference on Transparent Optical Networks, Munich, Germany, 27 June-1 July 2010; p. 1.

81. Tabares, J.; Ghasemi, S.; Polo, V.; Prat, J. Simplified Carrier Recovery for Intradyne Optical PSK Receivers in udWDM-PON. J. Lightw. Technol. 2018, 36, 2941-2947. [CrossRef]

82. Li, Z.; Dong, Y.; Wang, Y.; Lu, C. A novel PSK-manchester Modulation format in 10-gb/s passive optical network system with high tolerance to beat interference noise. IEEE Photonics Technol. Lett. 2005, 17, 1118-1120. [CrossRef]

83. Xiao, Q.; Chen, Y.; Lin, S.; He, H.; Wu, X.; You, J.; Zeng, Y.; Zhou, L.; Dong, Z. DFT-Spread DMT-WDM-PON Employing LDPC-Coded Probabilistic Shaping 16 QAM. J. Lightw. Technol. 2020, 38, 714-722. [CrossRef]

84. Pittala, F.; Cano, I.N.; Bluemm, C.; Schaedler, M.; Calabro, S.; Goeger, G.; Brenot, R.; Xie, C.; Shi, C.; Liu, G.N.; et al. 400-Gbit/s DP-16-QAM Transmission Over 40-km Unamplified SSMF With Low-Cost PON Lasers. IEEE Photonics Technol. Lett. 2019, 31, 1229-1232. [CrossRef] 
85. Lazarou, I.; Dris, S.; Bakopoulos, P.; Schrenk, B.; Avramopoulos, H. Full-Duplex 4-PAM Transmission for Capacity Upgrade in Loop-Back PONs. IEEE Photonics Technol. Lett. 2013, 25, 1125-1128. [CrossRef]

86. Stamatiadis, C.; Matsumoto, R.; Yoshida, Y.; Agata, A.; Maruta, A.; Kitayama, K.-I. Full-Duplex RSOA-Based PONs Using 4-PAM With Pre-Equalization. IEEE Photonics Technol. Lett. 2015, 27, 73-76. [CrossRef]

87. Wei, J.L.; Grobe, K.; Griesser, H. High speed next generation passive optical networks: performance, cost, and power dissipation. In Proceedings of the 2016 Progress in Electromagnetic Research Symposium (PIERS), Shanghai, China, 8-11 August 2016; pp. 4856-4857.

88. Sales, V.; Segarra, J.; Polo, V.; Velásquez, J.C.; Prat, J. UDWDM-PON Using Low-Cost Coherent Transceivers With Limited Tunability and Heuristic DWA. J. Opt. Commun. Netw. 2016, 8, 582-599. [CrossRef]

89. Tamai, H.; Sarashina, M.; Iwamura, H.; Kashima, M.; Gupta, G.C.; Ushikubo, T.; Kamijoh, T.; Chanclou, P.; Genay, N.; Landousies, B.; et al. First Demonstration of Coexistence of Standard Gigabit TDM-PON and Code Division Multiplexed PON Architectures Toward Next Generation Access Network. J. Lightw. Technol. 2009, 27, 292-298. [CrossRef]

90. Kashima, M.; Gupta, G.C.; Iwamura, H.; Tamai, H.; Watanabe, R.; Ushikubo, T.; Kamijoh, T. 42-dB loss budget hybrid DWDM-CDM-PON without optical amplifier. Electron. Lett. 2007, 43, 49-50. [CrossRef]

91. Yin, H.; Richardson, D.J. Optical Code Division Multiple Access Communication Networks: Theory and Applications; Springer: Berlin/Heidelberg, Germany, 2009; p. 382.

92. Shieh, W.; Djordjevic, I. OFDM for Optical Communications; Academic Press: Cambridge, MA, USA, 2009; p. 456.

93. Yu, J.; Huang, M.-F.; Qian, D.; Chen, L.; Chang, G.-K. Centralized Lightwave WDM-PON Employing 16-QAM Intensity Modulated OFDM Downstream and OOK Modulated Upstream Signals. IEEE Photonics Technol. Lett. 2008, 20, 1545-1547. [CrossRef]

94. Cano, I.N.; Escayola, X.; Schindler, P.C.; Santos, M.C.; Polo, V.; Leuthold, J.; Tomkos, I.; Prat, J. Experimental Demonstration of a Statistical OFDM-PON With Multiband ONUs and Elastic Bandwidth Allocation [Invited]. J. Opt. Commun. Netw. 2015, 7, A73-A79. [CrossRef]

95. Yang, H.; Li, J.; Lin, B.; Wan, Y.; Guo, Y.; Zhu, L.; Li, L.; He, Y.; Chen, Z. DSP-Based Evolution From Conventional TDM-PON to TDM-OFDM-PON. J. Lightw. Technol. 2013, 31, 2735-2741. [CrossRef]

96. Chen, H.-Y.; Wei, C.-C.; Lu, I.-C.; Chu, H.-H.; Chen, Y.-C.; Chen, J. High-Capacity and High-Loss-Budget OFDM Long-Reach PON Without an Optical Amplifier [Invited]. J. Opt. Commun. Netw. 2015, 7, A59-A65. [CrossRef]

97. Yoshimoto, N.; Kani, J.-I.; Kim, S.-Y.; Iiyama, N.; Terada, J. DSP-based optical access approaches for enhancing NG-PON2 systems. IEEE Commun. Mag. 2013, 51, 58-64. [CrossRef]

98. Birk, M.; Gerard, P.; Curto, R.; Nelson, L.; Zhou, X.; Magill, P.; Schmidt, T.J.; Malouin, C.; Zhang, B.; Ibragimov, E.; et al. Coherent $100 \mathrm{~Gb}$ /s PM-QPSK field trial. IEEE Commun. Mag. 2010, 48, 52-60. [CrossRef]

99. Nosu, K. Advanced coherent lightwave technologies. IEEE Commun. Mag. 1988, 26, 15-21. [CrossRef]

100. Semrau, D.; Xu, T.; Shevchenko, N.A.; Paskov, M.; Alvarado, A.; Killey, R.I.; Bayvel, P. Achievable information rates estimates in optically amplified transmission systems using nonlinearity compensation and probabilistic shaping. Opt. Lett. 2017, 42, 121-124. [CrossRef] [PubMed]

101. Dong-Nhat, N.; Nguyen, L.; Malekmohammadi, A. Using duobinary with first- and second-order optical equalisers for extending transmission distance of optical access networks. IET Optoelectron. 2018, 12, 239-243. [CrossRef]

102. Teixeira, A.; Lavery, D.; Ciaramella, E.; Schmalen, L.; Iiyama, N.; Ferreira, R.M.; Randel, S. DSP Enabled Optical Detection Techniques for PON. J. Lightw. Technol. 2020, 38, 684-695. [CrossRef]

103. Cho, K.Y.; Tanaka, K.; Sano, T.; Jung, S.P.; Chang, J.H.; Takushima, Y.; Agata, A.; Horiuchi, Y.; Suzuki, M.; Chung, Y.C. Long-Reach Coherent WDM PON Employing Self-Polarization-Stabilization Technique. J. Lightw. Technol. 2011, 29, 456-462. [CrossRef]

104. Suzuki, N.; Miura, H.; Matsuda, K.; Matsumoto, R.; Motoshima, K. 100 Gb/s to 1 Tb/s Based Coherent Passive Optical Network Technology. J. Lightw. Technol. 2018, 36, 1485-1491. [CrossRef]

105. Matsuda, K.; Suzuki, N. Hardware-Efficient Signal Processing Technologies for Coherent PON Systems. J. Lightw. Technol. 2019, 37, 1614-1620. [CrossRef]

106. Koma, R.; Fujiwara, M.; Kani, J.-I.; Suzuki, K.-I.; Otaka, A. Burst-Mode Digital Signal Processing That Pre-Calculates FIR Filter Coefficients for Digital Coherent PON Upstream. J. Opt. Commun. Netw. 2018, 10, 461-470. [CrossRef] 
107. Kim, S.-Y.; Kani, J.-I.; Terada, J. Performance Analysis of Phase Noise Cancellation by Asymmetric CMA for Realizing Affordable Coherent PON Transceivers. J. Lightw. Technol. 2020, 38, 2231-2241. [CrossRef]

108. Zhang, J.; Guo, C.; Liu, J.; Wu, X.; Lau, A.P.T.; Lu, C.; Yu, S. Decision-Feedback Frequency-Domain Volterra Nonlinear Equalizer for IM/DD OFDM Long-Reach PON. J. Lightw. Technol. 2019, 37, 3333-3342. [CrossRef]

109. Xu, T.; Liga, G.; Lavery, D.; Thomsen, B.C.; Savory, S.J.; Killey, R.I.; Bayvel, P. Equalization enhanced phase noise in Nyquist-spaced superchannel transmission systems using multi-channel digital back-propagation. Sci. Rep. 2015, 5, 1-13. [CrossRef] [PubMed]

110. van Veen, D.T.; Houtsma, V.E. Proposals for Cost-Effectively Upgrading Passive Optical Networks to a 25G Line Rate. J. Lightw. Technol. 2017, 35, 1180-1187. [CrossRef]

(C) 2020 by the authors. Licensee MDPI, Basel, Switzerland. This article is an open access article distributed under the terms and conditions of the Creative Commons Attribution (CC BY) license (http://creativecommons.org/licenses/by/4.0/). 